\title{
On-farm Assessments of Pasture Rejuvenation Methods on Soil Quality Indicators in Northern Alberta (Canada)
}

\author{
Akim Omokanye ${ }^{1}$, Calvin Yoder ${ }^{2}$, Lekshmi Sreekumar $^{1}$, Liisa Vihvelin $^{1} \&$ Monika Benoit ${ }^{1}$ \\ ${ }^{1}$ Peace Country Beef and Forage Association, Room 229 TIB, Grande Prairie Regional College, Fairview \\ Campus, Box 3000, Fairview Alberta, T0H 1L0, Canada \\ ${ }^{2}$ Alberta Agriculture and Forestry, Provincial Building, 4602 - 50 Street, Spirit River Alberta, T0H 3G0, Canada \\ Correspondence: Akim Omokanye, Peace Country Beef and Forage Association, Room 229 TIB, Grande Prairie \\ Regional College, Fairview Campus, Box 3000, Fairview Alberta, T0H 1L0, Canada. Tel: 1-780-835-6799. \\ E-mail: akim@pcbfa.ca
}

Received: March 17, 2018 Accepted: April 4, 2018 Online Published: April 20, 2018

doi:10.5539/sar.v7n2p74 URL: https://doi.org/10.5539/sar.v7n2p74

\begin{abstract}
The study was aimed at providing livestock producers with options on practical methods to improve soil quality of pastures for improved forage production and livestock carrying capacity. The study was carried out on-farm from 2015 to 2017 at two sites in northern Alberta, Canada. The methods of rejuvenation (treatments) evaluated were: sub-soiling, break \& re-seed (pasture renewal), a combination of manure application plus subsoiling, pasture rest, inorganic fertilizer application, high stock density grazing and bale grazing. A check/control treatment was included for comparison. For break \& re-seed, the forage mixture seeded $\left(16.8 \mathrm{~kg} \mathrm{ha}^{-1}\right)$ consisted of $60 \%$ grasses and $40 \%$ legumes. Overall, bale grazing improved soil organic matter (SOM) by up to $3.80 \%$ over other methods including check. In terms of soil compaction penetration resistance, water infiltration rate, water content and nutrients particularly N, P and K, bale grazing system as a method of rejuvenating old pastures significantly showed higher values than check at both sites. Without having to break and re-seed old pastures, the first option that livestock producers would have success with in improving soil quality for better pasture productivity would be bale grazing. The next two methods or rejuvenation strategies with great potential for improving soil conditions for pastures would be a combination of manure application plus subsoil in fall and high stock density grazing.
\end{abstract}

Keywords: break \& reseed, bale grazing, sub-soiling, organic matter, soil nutrients, soil quality, pastures

\section{Introduction}

In Canada, the province of Alberta alone accounted for about $40 \%$ of the national cattle herd in 2011, with pasture land accounting for $43 \%$ of total farm area (Statistics Canada, 2012). Cow-calf producers know that grazing on productive pastures can be very profitable on their operations. However, over time, in northern Alberta, the productivity and livestock carrying capacity of pastures on beef cattle operations would usually decline, largely a result of reduced plant stand vigor, which is mostly a consequence of soil compaction, occasional lack of moisture (drought), pests, weeds, overgrazing and poor soil fertility (Omokanye, 2015). Land degradation under pastures may occasionally be irreversible or expensive to rejuvenate, would have a major impact on the biodiversity and productivity of the pasture land. Therefore, producing high quality forage and maintaining productive pastures is a major challenge livestock producers encounter. Breaking and reseeding old pastures (renewal) or using other methods of rejuvenation can be a complex and costly challenge, as well as time consuming for producers. Recently, Omokanye et al. (2018) showed that breaking and reseeding an old pasture would require a minimum of CAD $\$ 625 /$ ha in cost in northern Alberta. The high costs associated with break \& re-seeding is making livestock producers to look at other strategies or rejuvenation methods that are practicable and cost less for sustaining a forage stand while improving or maintaining soil quality longer.

An available option for the implementation of such practice strategies is through the concept of soil quality proposed by Karlen et al. (1997). Soil quality is the capacity of a specific kind of soil to function, within natural or managed ecosystem boundaries, to sustain plant and animal productivity, maintain or enhance water and air quality, and support human health and habitation. The concept of soil quality is determined by inherent and dynamic characteristics of the soil (Karlen et al., 2003), and is found valid when indicator parameters such as 
permeability and penetration resistance are present, and such parameters will allow for evaluation of the level of soil quality (Reynolds et al., 2009; Horn \& Fleige, 2009). Soil quality indicators are those measurable soil properties and processes that have greatest sensitivity to changes in soil function and its ecosystem services (Zornoza et al., 2015; Andrews et al., 2004).

Soil compaction resulting from cattle trampling in pastures could reduce soil respiration by reducing pore space and limiting $\mathrm{O}_{2}$ diffusion (Collin \& van der Driessche, 2000; Shestak \& Busse, 2005). Reduced soil respiration may indicate less microbial activity and anaerobic conditions, both of which could negatively affect forage yield. If this situation persists, anaerobic conditions in the root zone could negatively affect plant growth (Linn \& Doran, 1984). This is because soil compaction can impair water infiltration into soil, root penetration and nutrient uptake, and consequently, the profitability of the beef cattle operation is negatively affected in northern Alberta (Omokanye, 2015). Where soil condition is good, the soil would have great potential to absorb and store water (rain and melted snow), store and recycle nutrients, provide habitat for seed germination and growth and consequently resist erosion. Remediation of compaction through subsoiling is one approach which producers can use on pastures.

Northern Alberta has a high content of expanding clay mineral soils often referred to as 'gumbo' and are classified in the vertisolic order (Soil Classification Working Group, 1998). These are mainly heavy-textured (mostly $>60 \%$ clay, with one-half of the clay being smectite minerals) soils. The 'gumbo' soils are characterized by a tough, impermeable hardpan that may vary from 5 to $30 \mathrm{~cm}$ or more below the surface (Lickacz, 1993). Some of the properties of the soils include the high shrink-swell potential, low bearing capacity and extreme stickiness when wet. This hardpan severely restricts root and water penetration of the subsoil (Lickacz, 1993).

Therefore, on-farm investigations on methods of rejuvenation of old pastures on "gumbo soils" that can lead to increase in soil nutrients, organic matter, microbial activity and earthworm populations, and with positive effects on soil aggregation and macro porosity would be of particular importance to livestock producers in northern Alberta. For the majority of prairie (grasslands) soils in western Canada, $\mathrm{N}$ is typically the most deficient nutrient, followed by $\mathrm{P}, \mathrm{K}$, and then S (AAF, 2008). An important part of efficient livestock production is ensuring there is sufficient grass for both hay and pastures. However, low soil nutrient levels often limit forage production. With good soil fertility and fertilizer management, the productivity of many hay and pasture fields can be greatly improved.

In addition to breaking and reseeding as a means of pasture renewal, one option that some producers have used in rejuvenating pastures is bale grazing. Bale grazing on fields is a method of providing feed to beef cattle particularly during the winter months, in the later parts of the fall or in early spring.

The objective of this study was to investigate how to manage degraded soil under grazing systems with minimal environmental effects, as well as to demonstrate practical and identify potential methods for improved soil quality for sustainable pasture production.

\section{Methods}

\subsection{Study Sites Characteristics}

Field experiments were carried out on-farm at two sites in northern Alberta, Canada from May 2015- July 2017. Both sites had cow-calf beef operations. Site 1 was located at Rycroft $\left(50^{\circ} 12^{\prime} \mathrm{N}, 111^{\circ} 08^{\prime} \mathrm{E}\right.$; altitude $765 \mathrm{~m}$ above sea level) on calcareous brown chernozem soil type. Site 2 was located at Grovedale $\left(55^{\circ} 02^{\prime} \mathrm{S}, 118^{\circ} 09^{\prime}\right.$ $\mathrm{W}$; altitude $676 \mathrm{~m}$ above sea level) on gleyed solonetzic gray luvisol soil type. The soil physical and chemical characteristics (0-15 \& 15-30 cm soil depths) at both experimental sites are provided in Table 1 . 
Table 1. Soil characteristics $(0-15 \& 15-30 \mathrm{~cm})$ for both sites before treatments in June 2015

\begin{tabular}{lllll}
\hline & \multicolumn{2}{l}{ Site 1: Rycroft Alberta } & \multicolumn{2}{l}{ Site 2: Grovedale Alberta } \\
\cline { 2 - 5 } & $0-15 \mathrm{~cm}$ & $15-30 \mathrm{~cm}$ & $0-15 \mathrm{~cm}$ & $15-30 \mathrm{~cm}$ \\
\hline Nutrients and quality: & & & & \\
Soil organic matter (SOM) & 5.2 & 4.3 & 6.9 & 3.8 \\
pH (1:2.5 H2O) & 5.7 & 7.1 & 6.9 & 6.9 \\
EC (dS/m) & 0.34 & 0.32 & 0.31 & 0.24 \\
$\mathrm{~N}^{*}(\mathrm{ppm})$ & 5 & 2 & 14 & 6 \\
Bary 1-P (ppm) & 19 & 18 & 9 & 7 \\
K (ppm) & 498 & 197 & 194 & 234 \\
S** (ppm) & 4 & 3 & 4 & 4 \\
Ca (ppm) & 3070 & 2550 & 1940 & 2280 \\
Mg (ppm) & 465 & 642 & 276 & 507 \\
Particle size analysis: & & & & \\
Sand (\%) & 14.6 & - & 46.7 & - \\
Silt (\%) & 46.8 & - & 37.8 & - \\
Clay (\%) & 38.6 & - & 15.5 & - \\
Soil texture & Silt clay loam & - & Loam & - \\
$\%$ Nutrient saturation: & Site 1 & - & Site 2 & - \\
Ca (\%) & 59.8 & - & 75.3 & - \\
Mg (\%) & 14.9 & - & 17.7 & - \\
Na (\%) & 0.45 & - & 0.8 & - \\
K (\%) & 5 & - & 3.9 & - \\
\% Base saturation (\%Ca + Mg + K) & 79.7 & - & 96.9 & - \\
TEC (meq/100g) & 25.6 & - & 12.8 & - \\
\hline
\end{tabular}

*Nitrate-N; **Sulphate-S

Both sites have a subarctic climate (also called boreal climate), which is characterized by long, usually very cold winters, and short, cool to mild summers. Weather data at both sites during the study as well as long-term averages are shown in Table 2.

Table 2. Rainfall, maximum \& minimum air temperatures during the study and long-term averages (LTA, 30 years average) at the study sites ${ }^{\mathrm{Z}}$

\begin{tabular}{lrrrrrrrr}
\hline & \multicolumn{3}{c}{ Site 1: Rycroft* } & \multicolumn{5}{c}{ Site 2: Grovedale** } \\
\cline { 2 - 9 } & 2015 & 2016 & \multicolumn{1}{c}{ 2017 } & \multicolumn{1}{c}{ LTA } & 2015 & 2016 & 2017 & LTA \\
\hline Rainfall (mm): & & & & & & & \\
\hline April & 24.5 & 6.9 & 29.7 & 22.3 & 33.5 & 19.1 & 44.3 & 21.1 \\
May & 15.4 & 61.6 & 41.3 & 39.2 & 24.8 & 72.7 & 75.1 & 37.5 \\
June & 34.9 & 69.5 & 40.8 & 69.9 & 136.5 & 163.8 & 39.3 & 70.9 \\
July & 19.0 & 74.1 & 33.6 & 70.8 & 22.8 & 54.2 & 45.4 & 68.9 \\
August & 57.7 & 53.8 & 31.8 & 51.1 & 49.8 & 137.7 & 42.3 & 56.1 \\
September & 29.8 & 48.1 & 50.2 & 38.5 & 39.5 & 30.9 & 91.7 & 40.0 \\
Total & 181.3 & 314.0 & 227.4 & 291.8 & 306.9 & 478.4 & 338.1 & 294.5 \\
\hline Maximum temperatures $\left({ }^{\circ} \mathrm{C}\right):$ & & & & & & \\
\hline April & 25.0 & 29.2 & 13.7 & 9.33 & 23.8 & 29.4 & 14.4 & 9.45 \\
May & 28.5 & 28.7 & 28.2 & 16.3 & 27.8 & 27.6 & 27.1 & 16.4 \\
June & 30.0 & 28.4 & 30.4 & 20.1 & 28.7 & 28.1 & 28.6 & 20.1 \\
July & 30.9 & 27.7 & 29.5 & 21.9 & 31.0 & 28.2 & 29.2 & 22.1 \\
August & 27.3 & 27.4 & 29.7 & 21.1 & 26.7 & 26.9 & 30.8 & 21.4 \\
September & 27.4 & 25.8 & 30.7 & 16.0 & 27.9 & 24.8 & 28.7 & 16.3 \\
\hline Minimum temperatures $\left({ }^{\circ} \mathrm{C}\right):$ & & & & & & \\
\hline April & -6.37 & -5.44 & -13.5 & -2.59 & -5.10 & -4.70 & -6.80 & -2.63 \\
May & -4.44 & -4.68 & -0.69 & 3.11 & -2.80 & -3.00 & -2.10 & 3.17 \\
June & 2.05 & 5.33 & 2.15 & 7.56 & 4.60 & 4.70 & 2.90 & 7.47 \\
July & 3.86 & 5.96 & 5.98 & 9.44 & 6.00 & 4.30 & 4.30 & 9.39 \\
August & -2.14 & 6.12 & 3.37 & 8.16 & 1.40 & 6.70 & 4.40 & 8.10 \\
September & -3.96 & -5.00 & -3.36 & 3.69 & -4.60 & -3.90 & -4.20 & 3.56 \\
\hline
\end{tabular}

*, weather station is $8.6 \mathrm{~km}$ from site 1. **, weather station is $32.4 \mathrm{~km}$ from site 2 .

${ }^{\mathrm{z}}$ Source: Alberta Agriculture \& Forestry, Canada

(https://agriculture.alberta.ca/acis/alberta-weather-data-viewer.jsp); The Weather Network Source (www.the weathernetwork.com).

\subsection{Pasture History and Management}

Site 1 pasture paddock was planted to a mixture of meadow bromegrass (Bromopsis biebersteinii, variety- Fleet), 
and alfalfa (Medicago sativa, variety name was not known) 15 years before the start of the experiment. The entire pasture paddock was about $30 \mathrm{ha}$, out of which a section (4 ha) was used for this experiment. The paddock was used strictly for pasture for 5 years before the experiment commenced.

Site 2 was also planted to similar forage mixture as site 1 about 16 years before the experiment started. At this site, 4 ha were also used for the experiment. The entire pasture paddock out of which 4 ha was used was 57 ha in size and had been grazed yearly by cow-calf pairs.

At both sites, pastures were grazed by Angus beef cattle each year, primarily in spring/summer. The pastures at both sites had declined in forage productivity over the years. Forage dry matter (DM) yield at the sites just before the start of the experiments averaged $1093 \mathrm{~kg} \mathrm{ha}^{-1}$ at Site 1 and $896 \mathrm{~kg} \mathrm{ha}^{-1}$ at Site 2 or $<20 \%$ of expected yearly forage DM yield from a productive pasture. At both sites, there was still a scanty amount of initial fleet bromegrass and alfalfa. The sites were later dominated mainly by quack grass (Elytrigia repens) and dandelions (Taraxacum officinale). Quack grass is a competitive perennial weed, which spreads rapidly by seed or underground stems (called rhizomes) and can be difficult to control (Nelson \& Hall, 2000). Dandelions is a flowering herbaceous perennial plant of the family Asteraceae (Compositae). Without appropriate weed control measures targeting dandelions and quack grass in pastures, both weeds have the potential to spread rapidly. Some producers consider both quack grass and dandelions as undesirable plants on pastures.

\subsection{Experimental Design and Methods of Rejuvenation of Pastures (Treatments)}

The treatments (methods of pasture rejuvenation) were set up using a randomized complete block design with three (3) replications at each site. Each treatment plot was $10 \mathrm{~m} \times 100 \mathrm{~m}\left(1000 \mathrm{~m}^{2}\right)$ in size. The methods of pasture rejuvenation that were evaluated at the sites and their descriptions are provided in Table 3 below. 
Table 3. A list of methods of pasture rejuvenation treatments investigated and brief description of activities carried out at both sites. The legumes were pre-inoculated

\begin{tabular}{|c|c|c|}
\hline Rej & $\begin{array}{l}\text { croft Alberta } \\
\text { eef farm) }\end{array}$ & $\begin{array}{l}\text { Site 2: Grovedale Alberta } \\
\text { Conventional beef farm) }\end{array}$ \\
\hline 1. C & & \\
\hline $\begin{array}{l}\text { 2. Spread beef cattle manure, followed by sub-soiling }(\mathrm{M}+\mathrm{S}) \text { to } 30 \mathrm{~cm} \text { soil depth } \\
\text { in the fall with an Agrowplow subsoiler (model AP11). The AP11 had } 7 \text { shanks } \\
\text { with } 32.5 \mathrm{~cm} \text { shank spacings. The shanks have a narrow opener, designed so they } \\
\text { fracture the soil profile downward but create very little soil disturbance and little } \\
\text { soil mixing. See Table } 4 \text { for manure } \mathrm{N} \text { content and application rate. The manure } \\
\text { was applied in the form of surface broadcasting with a manure spreader. }\end{array}$ & $\begin{array}{l}\text { Manure spread on } 29 \\
\text { October, 2015; at a rate } \\
\text { of } 58 \mathrm{~kg} \text { available } \mathrm{N} / \mathrm{ha} \\
\text { was applied. }\end{array}$ & $\begin{array}{l}\text { Treatment } 2 \text { not done at } \\
\text { this site. }\end{array}$ \\
\hline $\begin{array}{l}\text { 3. Sub-soiling in fall (SSF) to a soil depth of } 30 \mathrm{~cm} \text { in the fall with an } \\
\text { Agrowplow subsoiler, Model AP11. }\end{array}$ & $\begin{array}{l}\text { Sub-soiling done on } 31 \\
\text { October, } 2015 .\end{array}$ & $\begin{array}{l}\text { Sub-soiling done on } 30 \\
\text { October, } 2015 \text {. }\end{array}$ \\
\hline $\begin{array}{l}\text { 4. Pasture rest - no grazing or haying at all in } 2015 \text { only. An electric fence was } \\
\text { used to prevent cows from grazing this treatment in } 2015 \text {. } \\
\text { 5. Break \& re-seed (pasture renewal, B\&R) - The existing pasture was } \\
\text { completely cultivated (plowing, disking \& harrow) and then reseeded with a } \\
\text { forage mixture, which consisted of } 60 \% \text { smooth bromegrass (Bromus inermis } \\
\text { Leyss, variety-Carlton), } 10 \% \text { cicer milkvetch (Astragalus cicer, variety- Oxley II) } \\
\text { and } 30 \% \text { alfalfa (variety- Algonquin), making the mixture to be in a ratio of } 60 \% \\
\text { grass: } 40 \% \text { legume. The legume seeds were pre-inoculated. The forage seed was } \\
\text { seeded at the of } 16.8 \mathrm{~kg} \mathrm{ha}^{-1} \text { using a Fabro drill with } 23 \mathrm{~cm} \text { row spacing. }\end{array}$ & $\begin{array}{l}\text { The pasture paddock was } \\
\text { rested all year. } \\
\text { The forage seed on } 16 \\
\text { June } 2015 \text {. }\end{array}$ & $\begin{array}{l}\text { Treatment } 3 \text { not done at } \\
\text { this site. } \\
\text { The forage seed on } 18 \text { June } \\
2015 \text {. }\end{array}$ \\
\hline $\begin{array}{l}\text { 6. High stock density grazing (HSDG) of pasture for a short time to create a mob } \\
\text { grazing effect (mob grazing). The purpose was to create a major disturbance by } \\
\text { allowing the cows to graze in a short period of time, followed by an extended } \\
\text { period of pasture rest (only done once in } 2015 \text { ). Efforts were made no to allow } \\
\text { the cows to graze down completely. Cows only grazed about } 65 \% \text { of forage, with } \\
\text { the remaining } 35 \% \text { knocked down as plant litter. Cows were contained within the } \\
\text { plots with an electric fence. Assumption: } 1.0 \text { livestock units/head for cows } \\
\text { (including suckling calves) and that cows would be kept } 3 \text { months/year. }\end{array}$ & $\begin{array}{l}\text { Used } 173 \text { livestock unit } \\
\text { ha }^{-1} \text {. Grazing was done } \\
\text { on } 25 \text { July, } 2015 \text {. }\end{array}$ & $\begin{array}{l}\text { Used } 117 \text { livestock unit } \\
\mathrm{ha}^{-1} \text {. Grazing was done on } \\
30 \text { July, } 2015 \text {. }\end{array}$ \\
\hline $\begin{array}{l}\text { 7. Bale grazing (BG) practice in winter. This practice involves setting dry hay } \\
\text { bales out across a pasture or hay field from fall through winter to early spring. } \\
\text { Used a density of } 60 \text { hay bales/hectare that averaged } 545 \mathrm{~kg} / \mathrm{hay} \text { bale at each site. } \\
\text { Hay bales were place on a grid of } 12 \mathrm{~m} \text { centers (leaving } 10 \mathrm{~m} \text { ) between the hay } \\
\text { bales, to allow even manure nutrient coverage). Hay bale feed composition is } \\
\text { shown in Table } 4 \text {. Cows were contained within the plots with an electric fence. }\end{array}$ & $\begin{array}{l}70 \text { cows with average } \\
\text { live weight of } 545 \mathrm{~kg} \\
\text { were used to graze the } \\
\text { hay bales. Grazing } \\
\text { started on } 18 \text { February, } \\
\text { 2016: }\end{array}$ & $\begin{array}{l}65 \text { cows with average live } \\
\text { weight of } 545 \mathrm{~kg} \text { were } \\
\text { used graze the hay bales. } \\
\text { Grazing started on } 18 \\
\text { February, } 2016 .\end{array}$ \\
\hline $\begin{array}{l}\text { 8. Fertilizer application (FA). Top dressing of commercial (inorganic) fertilizer } \\
\text { blend following soil tests recommendations. Agrowdrill (model AD230) was } \\
\text { used to drop the fertilizer on the surface soil with a minimal soil disturbance. } \\
\text { Fertilizer application was made the plot had been grazed in 2015. Cows were }\end{array}$ & $\begin{array}{l}\text { Treatment } 8 \text { not done at } \\
\text { this site }\end{array}$ & $\begin{array}{l}\text { Fertilizer blend applied (kg } \\
\left.\mathrm{ha}^{-1}\right) \text { was: } 58 \mathrm{~N}+60 \mathrm{P}+ \\
31 \mathrm{~K}+16 \mathrm{~S} \text { on } 16 \text { June, } \\
2015 \text {. }\end{array}$ \\
\hline
\end{tabular}

Except for Treatments $2(\mathrm{M}+\mathrm{S})$ and 3 (SSF), which were done in the fall of 2015, and treatment 7 (BG), which was done during the winter of 2015/2016, all other treatments were implemented in the summer of 2015 .

\subsection{Manure and Hay Bale Feed Samplings for Analysis}

The stockpiled beef cattle solid manure used for treatment method $\mathrm{M}+\mathrm{S}$ at site 1 was sampled from the top (outer layer), middle and bottom. A front end loader attached to a tractor was used to get to the middle and bottom of the stockpiled manure. The front end loader also helped to create a face to enable vertical sampling. All samples were mixed together thoroughly, sub-sampled, air-dried and later analyzed for ammonium-N, total N, total $\mathrm{P}$ and moisture content to enable the calculation of desired $\mathrm{N}$ rate (Table 4).

Feed samples of the hay bales used for bale grazing treatment (BG, treatment 7 , see Table 3) were taken by coring round hay bales with an electric forage sampler. Three samples were taken for each hay bale. The samples from all bales were bulked together for laboratory analysis to determine if the hay would provide adequate nutrition for dry gestating beef cows in mid pregnancy (NRC, 1996, 2000) during bale grazing. Feed analysis 
included (see Table 4): dry matter content, crude protein (CP), Ca, P, K, Mg, S, Na and total digestible nutrients (TDN).

Table 4. Manure $\mathrm{N}$ content and rate of application, feed composition of hay bales used for bale grazing at both sites

\begin{tabular}{lcc}
\hline & Site 1: Rycroft Alberta & Site 2: Grovedale Alberta \\
\hline Manure composition: & & \\
\hline $\mathrm{N}$ content $\left(\mathrm{g} \mathrm{kg}^{-1}\right)$ & 8.60 & $\mathrm{NA}^{\mathrm{Z}}$ \\
Application rate* $\left(\mathrm{Mg} \mathrm{ha}^{-1}\right)$ & 6.78 & $\mathrm{NA}$ \\
$\mathrm{N}$ rate $\left(\mathrm{kg} \mathrm{N} \mathrm{ha}^{-1}\right)$ & 58.3 & $\mathrm{NA}$ \\
\hline \multicolumn{2}{l}{ Feed composition of hay bales for bale grazing: } & 90.3 \\
Dry matter $(\%)$ & 91.1 & 12.8 \\
$\mathrm{Crude}$ protein $(\%)$ & 10.9 & 0.67 \\
$\mathrm{Ca}(\%)$ & 0.67 & 0.25 \\
$\mathrm{P}(\%)$ & 0.22 & 2.98 \\
$\mathrm{~K}(\%)$ & 2.70 & 0.24 \\
$\mathrm{Mg}(\%)$ & 0.24 & 58.9 \\
$\mathrm{TDN}(\%)$ & 55.6 & \\
\hline
\end{tabular}

*, The application rate for manure and feed composition are on a dry weight basis. A single application of manure was made in the fall of 2015 to meet the $\mathrm{N}$ requirements of existing forage stand.

${ }^{\mathrm{z}}$, Not available.

\subsection{Data Collection}

After all the treatments have been implemented from spring to fall of 2015 as well as early 2016 (during winter) for BG (treatment 7), field measurements for appropriate data collection were done in mid-July of 2016 \& 2017. All measurements and soil samples were collected using a consistent grid that had 3 points spaced $20 \mathrm{~m}$ apart imposed within the length of each treatment plot. Soil samplings and other measurements were taken within a radius of $3 \mathrm{~m}$ of each point. Soil samplings and field measurements were avoided within $20 \mathrm{~m}$ from the two edges along the plot length and $10 \mathrm{~m}$ from both sides of each treatment plot. The grid points therefore provided 3 sampling points for each treatment plot or 21 sampling points for Site 1 and 18 for Site 2.

Soil quality integrates the physical, chemical, and biological components of soil, and their interactions. We know that in order to capture the holistic nature of soil quality or health, all components of soils should be measured. However, in the present study, only physical and chemical components were measured. No biological component was measured.

\subsubsection{Field Measurements}

Soil water content - A direct measurement of soil water content from $0-15 \mathrm{~cm}$ soil depth was done with gravimetric method of soil water content determination as described by Gardner (1986). The soil was sampled with stainless steel soil sampler $(2.70 \mathrm{~cm}$ diameter). The soil was sampled at $30 \mathrm{~cm}$ depth per lift. The moist soil samples were weighed, air dried in the open for 10 days and later reweighed. The mass of water lost was calculated as a percentage of the mass of the dried soil. Thus, $\%$ of soil water (dry-mass basis) $=$ weight of wet soil (g) - weight of dry soil (g)/weight of dry soil (g) x 100.

Soil water infiltration - The water infiltration rate was measured with single-ring infiltrometers as described by Lowery et al. (1996) and Nicholas (2004). The ring infiltrometers (aluminized coated) were $15 \mathrm{~cm}$ in diameter and $14 \mathrm{~cm}$ in height. Using the sledge hammer and block of wood, the rings were hammered to $7.50 \mathrm{~cm}$ into the soil. The amount of time it took $500 \mathrm{~mL}$ of water to infiltrate was recorded.

Soil Compaction - Soil compaction penetration resistance readings were taken from 0-30 $\mathrm{cm}$ soil profile at 2.5 $\mathrm{cm}$ intervals. FieldScout SC 900 Soil Digital Compaction Meter (cone penetrometer) was used to collect soil compaction data.The compaction meter had exclusive ultrasonic depth sensor, which captured readings in $2.5 \mathrm{~cm}$ increments.

\subsubsection{Laboratory Measurements}

Within each replicate of a particular treatment, 3 soil cores each were collected from $0-15 \mathrm{~cm}$ and $15-30 \mathrm{~cm}$ using a step-down soil probe. We mixed samples taken from the same depth intervals. All samples were air dried and then analyzed in the laboratory for soil nutrients [nitrate- $\mathrm{N}(\mathrm{N}), \mathrm{P}, \mathrm{K}, \mathrm{S}, \mathrm{Ca}, \mathrm{Mg}$ ], soil organic matter (SOM), electrical conductivity (EC) and $\mathrm{pH}$. Three additional samples were collected from 0-15 and 15-30 cm soil layer 
with a soil sampler for each replication for total $\mathrm{C}$ and $\mathrm{N}$ and their resulting $\mathrm{C}: \mathrm{N}$ ratios.

Laboratory methods of analysis used following those described by McKeague (1978) were loss on ignition (LOI, 3.8) for SOM; water extraction (1:2 soil:water ratio, 4.12) for $\mathrm{pH}$;saturated paste extract for EC; ammonium acetate extractable cations, 4.51 for $\mathrm{P}, \mathrm{K}, \mathrm{Mg}$, and $\mathrm{Ca}$; and sulphate-S was by sulphate extractable by $0.1 \mathrm{M} \mathrm{CaCl}_{2}$, 4.47. Nitrate- $\mathrm{N}$ was determined using $0.01 \mathrm{M} \mathrm{K}_{2} \mathrm{SO}_{4}$ extraction and extract analysed colorimetrically (Standard Methods for the Examination of Water and Wastewater. 22nd Edition 4500- $\mathrm{NO}_{3}$; Automated Cadmium Reduction Method). Total C and N were analysed following the methods described by Nelson \& Sommers (1996) and their ratios were calculated for each of the rejuvenation methods.

Soil nutrient (N, P, K and S) levels were reported in parts per million (ppm). For each $15 \mathrm{~cm}$ sample depth, these values were doubled to approximate the nutrient levels on a $\mathrm{kg} \mathrm{ha}^{-1}$ (AAF, 2008). We are aware that most plants take up nitrogen in the form of dissolved nitrate $\left(\mathrm{NO}_{3}{ }^{-}\right)$and ammonium ions $\left(\mathrm{NH}_{4}{ }^{+}\right)$, but in this study, we would only be examining soil nitrate- $\mathrm{N}$.

\subsection{Data Analysis}

The collected data from the two locations were analyzed separately (site basis) and on a yearly basis using the GenStat statistical package $\left(2009,12^{\text {th }}\right.$ Edition). The values of soil quality indicators such as soil water content, water infiltration rate and compaction penetration resistance were compared among rejuvenation treatments by one-way ANOVA. Other parameters ( $\mathrm{pH}, \mathrm{SOM}, \mathrm{EC}, \mathrm{C}, \mathrm{N}, \mathrm{C}: \mathrm{N}$ ratios, N, P, K \& S) that were determined from 2 soil depths [0-15 cm (D1) \& 15-30 cm (D2)] were compared among rejuvenation treatments by two-way ANOVA. The resulting total soil N, P, K \& S from D1 \& D2 were not subjected to any statistical analysis. Where ANOVA indicated significant treatment effects for those parameters that were statistically analyzed, the means were separated by the least significant difference (LSD) at the 0.05 probability level. Significant differences in the text refer to $P<0.05$.

\section{Results}

\subsection{Site 1: Rycroft Alberta}

\subsubsection{Soil Physical Properties}

Soil Water Content (Table 5) - The soil water content was similar $(P>0.05)$ for all rejuvenation methods in 2016. But in 2017, BG had significantly $(P<0.05)$ higher soil water content than other methods including check. In 2017, other than BG, other rejuvenation methods had similar soil water content. Overall, in 2017, BG, SSF, M+S, and B\&R had 10-34\% higher soil water content than check.

Water Infiltration Rate (Table 5) - The water infiltration rate was significantly affected $(P<0.05)$ by methods of rejuvenation investigated for both years (2016 \& 2017). In 2016, infiltration rate was higher for SSF, M+S, BG, B\&R and HSDG than other rejuvenation methods. In 2017, the 2 subsoiling treatments (SSF and M+S) and $B \& R$ appeared to have far higher infiltration rates than other rejuvenation methods. Overall, SSF, M+S, B\&R and BG seemed to consistently infiltrated more water through the surface soil than other methods as well as check, even after about 2 years of implementing those rejuvenation methods.

Soil Compaction Penetration Resistance (Table 5, Figure 1) - In both years (2016 \& 2017), pooled over soil depths $(0$ to $30 \mathrm{~cm})$, the mean soil compaction readings (over soil depths) differed significantly $(P<0.05)$ for rejuvenation methods. The significant interactions showed that SOM was significantly lowest for SS The mean soil compaction in 2016 and 2017 appeared to be consistently improved by SSF, M+S, B\&R, and BG than other methods. In 2016, B\&R had the least mean compaction values, while in 2017, both B\&R and BG had the least mean compaction values (Table 5). 
Table 5. Gravimetric soil water content, water infiltration rate and mean soil compaction (averaged over depths) in 2016 and 2017 at Site 1: Rycroft Alberta

\begin{tabular}{lllllll}
\hline & \multicolumn{2}{l}{ Soil water content $(\%)$} & \multicolumn{2}{l}{ Infiltration $(\mathrm{mm} / \mathrm{hr})$} & \multicolumn{2}{l}{ Compaction $\left(\mathrm{kg} \mathrm{cm}^{-2}\right)$} \\
\hline Rejuvenation Method & 2016 & 2017 & 2016 & 2017 & 2016 & 2017 \\
\hline Check & 16.5 & 13.5 & 1.27 & 1.27 & 28.1 & 32.0 \\
Bale grazing & 16.4 & 18.1 & 18.3 & 13.7 & 16.4 & 9.56 \\
Break \& re-seed & 15.2 & 14.8 & 12.7 & 23.9 & 8.73 & 9.43 \\
Manure \& subsoil in fall & 16.5 & 15.5 & 15.0 & 27.7 & 19.3 & 10.2 \\
Subsoil in fall & 19.6 & 14.8 & 21.3 & 29.0 & 16.3 & 12.1 \\
High stock density grazing & 15.4 & 12.4 & 11.4 & 5.59 & 31.4 & 32.5 \\
Pasture rest & 18.7 & 13.0 & 5.33 & 4.57 & 20.5 & 31.4 \\
\hline Mean & 16.9 & 14.6 & 12.2 & 15.1 & 20.1 & 19.6 \\
Significance & $\mathrm{NS}$ & $* *$ & $* * *$ & $* * *$ & $* * *$ & $* * *$ \\
LSD & 5.05 & 2.20 & 6.60 & 7.87 & 10.8 & 8.09 \\
$\mathrm{CV}_{0} \%$ & 3.86 & 9.62 & 0.37 & 39.7 & 19.7 & 24.6 \\
\hline
\end{tabular}

${ }^{\mathrm{Z}}$, NS, not significant at $P<0.05$.

** and ***, significant at $P<0.01$ and $\mathrm{P}<0.001$, respectively.

$\mathrm{LSD}_{0.05}$, least significant difference at $P<0.05$.

$\mathrm{CV}$, coefficient of variation.

Pooled over 2 years ( 2016 \& 2017), the mean soil compaction readings from surface soil to $30 \mathrm{~cm}$ subsurface soil depth for each rejuvenation method showed that SSF, M+S, B\&R, BG consistently showed less compaction values than other rejuvenation methods (Figure 1).

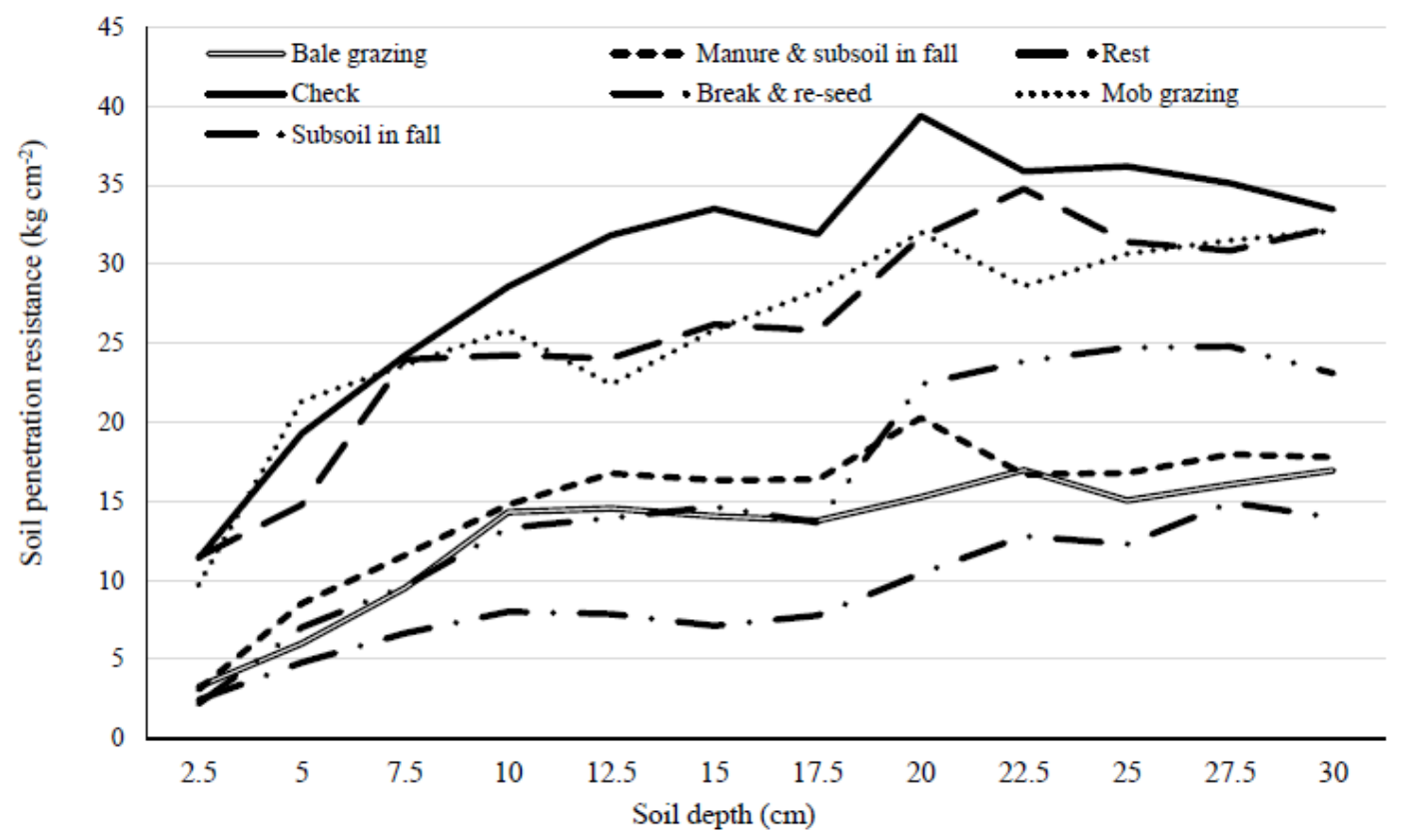

Figure 1. The mean (pooled over $2016 \& 2017$ ) soil compaction from 0 to $30 \mathrm{~cm}$ for different rejuvenation methods at Site 1: Rycroft Alberta. Significance: *** $(\mathrm{P}<0.001)$ LSD $_{0.05}$ : 7.97; Coefficient of variation $(\%): 16.7$

\subsubsection{Soil Chemical Properties}

Soil pH (Table 6) - The soil $\mathrm{pH}$ showed some significant differences $(P<0.05)$ for rejuvenation methods. On a general note, the soil $\mathrm{pH}$ values did not change drastically from 2016 to 2017 for any particular methods. The mean soil $\mathrm{pH}$ across rejuvenation methods was similar for both years and depths $(\sim 7.0 \mathrm{soil} \mathrm{pH})$.

Soil Organic Matter (SOM, Table 6) - There was significant $(P<0.05)$ method $\mathrm{x}$ soil depth interaction for SOM in both years ( $2016 \& 2017$. The significant interaction effects showed that in 2016, SOM was significantly least for HSDG (3.4\% SOM) and highest for M+S (8.4\%). In 2017, M+S also had the highest SOM (8.3\%), while occasionally resting the pasture treatment method gave the lowest SOM (4.10\%). Only BG and HSDG, and to some extent $\mathrm{M}+\mathrm{S}$ appeared to show some potential for slight consistent increases in surface SOM from 2016 to 
2017, with SOM increasing up to $1.1 \%$ for BG, $0.5 \%$ for M+S and $0.85 \%$ for HSDG. Generally, the surface soil had higher SOM values than subsurface soil for all treatments in both years.

Electrical Conductivity (EC, Table 6) - In both years, EC was influenced by method x soil depth interaction. In 2016, the methods mostly had higher EC in surface soil $(0-15 \mathrm{~cm})$ than the sub-surface soil $(15-30 \mathrm{~cm})$, while in 2017, 3 out of the 7 methods had higher soil EC in the sub-surface soil than surface soil. In both years, in the surface soil, BG seemed to show some tendencies for higher soil EC than other methods (except M+S in 2016). In the sub-surface soil, B\&R in 2016 and M+S in 2017 had higher soil EC than other methods in the respective years.

Table 6. Soil $\mathrm{pH}$, soil organic matter (SOM) and electrical conductivity (EC) from 2 depths $[0-15 \mathrm{~cm}$ (D1) \& 15-30 cm (D2)] in 2016 and 2017 at Site 1: Rycroft Alberta

\begin{tabular}{|c|c|c|c|c|c|c|c|c|c|c|c|c|}
\hline \multirow{3}{*}{ Rejuvenation method } & \multicolumn{4}{|c|}{$\mathrm{pH}$} & \multicolumn{4}{|c|}{$\operatorname{SOM}(\%)$} & \multicolumn{4}{|c|}{$\mathrm{EC}(\mathrm{dS} / \mathrm{m})$} \\
\hline & \multicolumn{2}{|c|}{2016} & \multicolumn{2}{|c|}{2017} & \multicolumn{2}{|c|}{2016} & \multicolumn{2}{|c|}{2017} & \multicolumn{2}{|c|}{2016} & \multicolumn{2}{|c|}{2017} \\
\hline & D1 & $\mathrm{D} 2$ & D1 & D2 & D1 & D2 & D1 & D2 & D1 & D2 & D1 & D2 \\
\hline Check & 7.1 & 6.4 & 6.8 & 6.8 & 6.5 & 3.8 & 6.3 & 4.5 & 0.27 & 0.22 & 0.10 & 0.10 \\
\hline Bale grazing & 6.6 & 6.6 & 7.0 & 7.0 & 7.1 & 4.3 & 8.2 & 5.0 & 0.55 & 0.17 & 0.44 & 0.30 \\
\hline Break \& re-seed & 6.4 & 7.3 & 6.5 & 6.5 & 8.1 & 5.9 & 6.5 & 6.4 & 0.29 & 0.42 & 0.03 & 0.24 \\
\hline Manure \& subsoil in fall & 7.2 & 7.1 & 7.0 & 6.9 & 8.4 & 3.8 & 8.3 & 6.2 & 0.52 & 0.27 & 0.32 & 0.32 \\
\hline Subsoil in fall & 7.3 & 7.5 & 7.0 & 7.0 & 7.4 & 4.8 & 6.4 & 5.9 & 0.40 & 0.34 & 0.25 & 0.29 \\
\hline High stock density grazing & 7.0 & 6.4 & 7.2 & 7.4 & 7.0 & 3.4 & 7.4 & 5.3 & 0.25 & 0.11 & 0.39 & 0.44 \\
\hline Pasture rest & 6.8 & 6.8 & 6.7 & 6.9 & 7.8 & 4.1 & 6.7 & 4.1 & 0.23 & 0.52 & 0.31 & 0.21 \\
\hline Mean & 6.9 & 6.9 & 6.9 & 7.0 & 7.5 & 4.2 & 6.8 & 4.9 & 0.35 & 0.26 & 0.26 & 0.25 \\
\hline Significance $(\mathrm{T} \times \mathrm{D})^{\mathrm{z}}$ & \multicolumn{2}{|c|}{$*$} & \multicolumn{2}{|c|}{$*$} & \multicolumn{2}{|c|}{$*$} & \multicolumn{2}{|c|}{$* * *$} & \multicolumn{2}{|c|}{ ** } & \multicolumn{2}{|c|}{$* *$} \\
\hline $\mathrm{LSD}_{0.05}(\mathrm{~T} \times \mathrm{D})$ & \multicolumn{2}{|c|}{0.3} & \multicolumn{2}{|c|}{0.4} & \multicolumn{2}{|c|}{0.31} & \multicolumn{2}{|c|}{0.3} & \multicolumn{2}{|c|}{0.19} & \multicolumn{2}{|c|}{0.09} \\
\hline $\mathrm{CV}, \%$ & \multicolumn{2}{|c|}{2.13} & \multicolumn{2}{|c|}{0.93} & \multicolumn{2}{|c|}{2.77} & \multicolumn{2}{|c|}{2.58} & \multicolumn{2}{|c|}{2.52} & \multicolumn{2}{|c|}{2.19} \\
\hline
\end{tabular}

${ }^{\mathrm{z}}, \mathrm{T} \times \mathrm{D}$, treatment (rejuvenation methods) $\mathrm{x}$ soil depths interaction

$*$, ** and $* * *$, significant at $\mathrm{p}<0.05, P<0.01$ and $\mathrm{P}<0.001$, respectively.

$\mathrm{LSD}_{0.05}$, least significant difference at $P<0.05$.

$\mathrm{CV}$, coefficient of variation.

Total C and N, and C:N ratio (Table 7) - In both years (2016 \& 2017), the soil $\mathrm{C}$ and $\mathrm{N}$ were significantly influenced by rejuvenation methods $\mathrm{x}$ soil depth interaction, but not the resulting $\mathrm{C}: \mathrm{N}$ ratios. The significant interaction effects for both soil $\mathrm{C}$ and $\mathrm{N}$ in both years showed that in most cases, soil $\mathrm{C}$ and $\mathrm{N}$ were significantly lower at the sub-surface soil $(15-30 \mathrm{~cm})$ than soil $\mathrm{C}$ and $\mathrm{N}$ at the surface soil $(0-15 \mathrm{~cm})$. The resulting lowest and highest values from the rejuvenation methods $\mathrm{x}$ soil depth interactions were:

C (2016): lowest for HSDG at $15-30 \mathrm{~cm}(1.58 \%)$ and highest for B\&R at $0-15 \mathrm{~cm}(3.53 \%)$

C (2017): lowest for HSDG at $15-30 \mathrm{~cm}(1.67 \%)$ and highest for BG at $0-15 \mathrm{~cm}(4.16 \%)$

$\mathrm{N}$ (2016): lowest for HSDG at $15-30 \mathrm{~cm}(0.15 \%)$ and highest for B\&R at $0-15 \mathrm{~cm}(0.46 \%)$

$\mathrm{N}$ (2017): lowest for Check $15-30 \mathrm{~cm}(0.16 \%)$ and highest for BG and HSDG at 0-15 cm (0.34\%)

Table 7. Soil total $\mathrm{C}$ and $\mathrm{N}$ and their ratios (C:N) from 2 depths [0-15 $\mathrm{cm}$ (D1) and 15-30 cm (D2)] in 2016 \& 2017 at Site 1: Rycroft Alberta

\begin{tabular}{|c|c|c|c|c|c|c|c|c|c|c|c|c|}
\hline \multirow{3}{*}{ Rejuvenation Method } & \multicolumn{4}{|c|}{ C \% } & \multicolumn{4}{|c|}{$\mathrm{N} \%$} & \multicolumn{4}{|c|}{ C:N ratio } \\
\hline & \multicolumn{2}{|c|}{2016} & \multicolumn{2}{|c|}{2017} & \multicolumn{2}{|c|}{2016} & \multicolumn{2}{|c|}{2017} & \multicolumn{2}{|c|}{2016} & \multicolumn{2}{|c|}{2017} \\
\hline & D1 & D2 & D1 & D2 & D1 & $\mathrm{D} 2$ & D1 & D2 & D1 & $\mathrm{D} 2$ & D1 & D2 \\
\hline Check & 4.33 & 1.69 & 3.51 & 1.79 & 0.36 & 0.16 & 0.27 & 0.16 & 12.0 & 10.6 & 13.0 & 11.2 \\
\hline Bale grazing & 4.85 & 2.06 & 4.16 & 2.19 & 0.39 & 0.19 & 0.34 & 0.20 & 12.4 & 10.8 & 12.2 & 11.0 \\
\hline Break \& re-seed & 5.35 & 3.57 & 3.00 & 1.95 & 0.46 & 0.30 & 0.28 & 0.17 & 11.6 & 11.9 & 10.7 & 11.5 \\
\hline Manure \& subsoil in fall & 5.12 & 2.15 & 2.62 & 1.83 & 0.42 & 0.21 & 0.23 & 0.18 & 12.2 & 10.2 & 11.4 & 10.4 \\
\hline Subsoil in fall & 5.00 & 2.81 & 3.50 & 2.17 & 0.44 & 0.27 & 0.30 & 0.20 & 11.4 & 10.4 & 11.7 & 11.1 \\
\hline High stock density grazing & 4.34 & 1.58 & 4.10 & 1.67 & 0.37 & 0.15 & 0.34 & 0.18 & 11.7 & 10.5 & 12.1 & 12.2 \\
\hline Pasture rest & 4.77 & 1.72 & 3.52 & 2.04 & 0.43 & 0.17 & 0.32 & 0.18 & 11.1 & 10.1 & 11.0 & 11.7 \\
\hline Mean & 4.82 & 2.23 & 3.49 & 1.95 & 0.41 & 0.21 & 0.30 & 0.18 & 11.8 & 10.6 & 11.7 & 11.3 \\
\hline Significance $(\mathrm{T} \times \mathrm{D})^{\mathrm{z}}$ & \multicolumn{2}{|c|}{$* * *$} & \multicolumn{2}{|c|}{$* * *$} & \multicolumn{2}{|c|}{ * } & \multicolumn{2}{|c|}{$*$} & \multicolumn{2}{|c|}{$\mathrm{NS}^{\mathrm{y}}$} & \multicolumn{2}{|c|}{ NS } \\
\hline $\mathrm{LSD}_{0.05}(\mathrm{~T} \times \mathrm{D})$ & \multicolumn{2}{|c|}{1.23} & \multicolumn{2}{|c|}{1.08} & \multicolumn{2}{|c|}{0.09} & \multicolumn{2}{|c|}{0.07} & \multicolumn{2}{|c|}{3.23} & \multicolumn{2}{|c|}{2.81} \\
\hline $\mathrm{CV}, \%$ & \multicolumn{2}{|c|}{5.23} & \multicolumn{2}{|c|}{4.98} & \multicolumn{2}{|c|}{1.23} & \multicolumn{2}{|c|}{2.17} & \multicolumn{2}{|c|}{3.33} & \multicolumn{2}{|c|}{2.54} \\
\hline
\end{tabular}

${ }^{\mathrm{z}}, \mathrm{T}$ x D, treatment (rejuvenation methods) $\mathrm{x}$ soil depths interaction.

${ }^{\mathrm{y}}$, NS, Not significant at $\mathrm{P}<0.05$. 
$*$, ** and $* * *$, significant at $\mathrm{p}<0.05, P<0.01$ and $\mathrm{P}<0.001$, respectively.

$\mathrm{LSD}_{0.05}$, least significant difference at $P<0.05 ; \mathrm{CV}$, coefficient of variation.

In 2016, B\&R, M+S and SSF in that order appeared to have higher soil total $C$ values in the $0-15 \mathrm{~cm}$ soil layer than other methods including check (Table 7). These rejuvenation methods (B\&R, M+S and SSF) also showed higher soil total $\mathrm{N}$ in the same soil layer.

Just as the resulting $\mathrm{C}: \mathrm{N}$ ratios, which did not show any significant rejuvenation methods $\mathrm{x}$ soil depth interaction, in both years, pooled over soil depths, the C:N ratios were also similar for all rejuvenation methods (data not shown).

Soil Nutrients (Table 8$)$ - In both years, there were significant rejuvenation methods $\mathrm{x}$ soil depths interactions $(P<0.05)$ for soil $\mathrm{N}, \mathrm{P}, \mathrm{K}$ and $\mathrm{S}$.

In 2016, in the surface soil $(0-15 \mathrm{~cm}), \mathrm{N}$ was greatly improved by HSDG and this was followed by BG. The HSDG method exceeded other methods including BG by $43-139 \mathrm{~kg}^{-1} \mathrm{~N}$. On the other hand, BG improved soil N by up to $96 \mathrm{~kg} \mathrm{ha}^{-1} \mathrm{~N}$ over other methods (excluding HSDG). In 2017, BG had the most soil $\mathrm{N}$ in the surface soil, followed by HSDG and then M+S. Except for B\&R in 2016 and M+S in 2017, the subsurface soil generally had lower soil $\mathrm{N}$ than surface soil. Overall, BG, M+S, HSDG and to some extent resting the field as a method of rejuvenation for a year have all shown some potential for improving soil $\mathrm{N}$ than other methods. The greater improvement in subsurface soil $\mathrm{N}$ appeared to be from BG and HSDG in 2017. In 2016, combining the 2 depths $(0-5 \mathrm{~cm}+15-30 \mathrm{~cm})$, HSDG had the highest soil $\mathrm{N}\left(\sim 150 \mathrm{~kg} \mathrm{ha}^{-1}\right)$, followed by BG $\left(105 \mathrm{~kg} \mathrm{ha}^{-1}\right)$ and then B\&R $\left(\sim 24 \mathrm{~kg} \mathrm{ha}^{-1}\right)$. In 2017, BG had the highest soil $\mathrm{N}$ at both depths $\left(\sim 96 \mathrm{~kg}^{-1}\right)$, followed by HSDG $\left(85 \mathrm{~kg} \mathrm{ha}^{-1}\right)$ and then pasture rest $\left(\sim 61 \mathrm{~kg} \mathrm{ha}^{-1}\right)$.

Table 8. Soil N, P, K \& S from 2 depths [0-15 cm (D1) \& 15-30 cm (D2)] in 2016 \& 2017 at Site 1: Rycroft Alberta

\begin{tabular}{|c|c|c|c|c|c|c|c|c|c|c|c|c|}
\hline \multirow{3}{*}{ Rejuvenation Method } & \multicolumn{6}{|c|}{$\mathrm{N}\left(\mathrm{kg} \mathrm{ha}^{-1}\right)$} & \multicolumn{6}{|c|}{$\mathrm{P}\left(\mathrm{kg} \mathrm{ha}^{-1}\right)$} \\
\hline & \multicolumn{3}{|c|}{2016} & \multicolumn{3}{|c|}{2017} & \multicolumn{3}{|c|}{2016} & \multicolumn{3}{|c|}{2017} \\
\hline & D1 & $\mathrm{D} 2$ & Total & D1 & D2 & Total & D1 & $\mathrm{D} 2$ & Total & D1 & $\mathrm{D} 2$ & Total \\
\hline Check & 11.2 & 4.48 & 15.7 & 13.4 & 6.72 & 20.1 & 42.6 & 17.9 & 60.5 & 29.1 & 26.9 & 56.0 \\
\hline Bale grazing & 100.8 & 4.48 & 105.3 & 62.7 & 33.6 & 96.3 & 71.7 & 31.4 & 103.1 & 56 & 40.3 & 96.3 \\
\hline Break \& re-seed & 11.2 & 12.3 & 23.5 & 15.7 & 11.2 & 26.9 & 29.1 & 22.4 & 51.5 & 35.8 & 29.1 & 64.9 \\
\hline Manure \& subsoil in fall & 4.48 & 4.48 & 8.96 & 15.7 & 26.9 & 42.6 & 134.4 & 35.8 & 170.2 & 47 & 33.6 & 80.6 \\
\hline Subsoil in fall & 4.48 & 4.48 & 8.96 & 8.96 & 15.7 & 24.7 & 29.1 & 15.7 & 44.8 & 20.2 & 22.4 & 42.6 \\
\hline High stock density grazing & 143.4 & 4.48 & 147.9 & 44.8 & 40.3 & 85.1 & 85.1 & 26.9 & 112 & 44.8 & 31.4 & 76.2 \\
\hline Pasture rest & 4.48 & 4.48 & 8.96 & 40.3 & 20.2 & 60.5 & 31.4 & 17.9 & 49.3 & 26.9 & 29.1 & 56.0 \\
\hline Mean & 40.0 & 5.60 & & 28.8 & 22.1 & & 60.5 & 24.0 & & 37.1 & 30.4 & 67.5 \\
\hline Significance $(\mathrm{T} \times \mathrm{D})^{\mathrm{Z}}$ & \multicolumn{3}{|c|}{$* * *$} & \multicolumn{3}{|c|}{$* * *$} & \multicolumn{2}{|c|}{$* * *$} & \multicolumn{4}{|c|}{$* * *$} \\
\hline $\mathrm{LSD}_{0.05}(\mathrm{~T} \times \mathrm{D})$ & \multirow{2}{*}{\multicolumn{2}{|c|}{$\begin{array}{l}1.99 \\
5.10\end{array}$}} & & \multicolumn{3}{|c|}{2.97} & \multicolumn{2}{|c|}{9.17} & \multicolumn{4}{|c|}{7.19} \\
\hline $\mathrm{CV}, \%$ & & & 5.10 & \multicolumn{2}{|c|}{6.00} & & \multicolumn{2}{|c|}{7.29} & \multicolumn{4}{|c|}{3.70} \\
\hline
\end{tabular}

\begin{tabular}{|c|c|c|c|c|c|c|c|c|c|c|c|c|}
\hline \multirow{3}{*}{ Rejuvenation Method } & \multicolumn{6}{|c|}{$\mathrm{K}\left(\mathrm{kg} \mathrm{ha}^{-1}\right)$} & \multicolumn{6}{|c|}{$\mathrm{S}\left(\mathrm{kg} \mathrm{ha}^{-1}\right)$} \\
\hline & \multicolumn{3}{|c|}{2016} & \multicolumn{3}{|c|}{2017} & \multicolumn{3}{|c|}{2016} & \multicolumn{3}{|c|}{2017} \\
\hline & D1 & D2 & Total & D1 & D2 & Total & D1 & D2 & Total & D1 & D2 & Total \\
\hline Check & 1116 & 423 & 1539 & 1021 & 647 & 1668 & 8.96 & 8.96 & 17.92 & 11.2 & 8.96 & 20.2 \\
\hline Bale grazing & 1275 & 780 & 2055 & 1324 & 939 & 2263 & 15.7 & 6.7 & 22.4 & 11.0 & 8.98 & 20.2 \\
\hline Break \& re-seed & 1230 & 388 & 1618 & 1042 & 786 & 1828 & 11.2 & 13.4 & 24.6 & 11.2 & 11.2 & 22.4 \\
\hline Manure \& subsoil in fall & 1198 & 831 & 2029 & 1225 & 793 & 2018 & 24.6 & 24.6 & 49.2 & 24.6 & 22.4 & 47.0 \\
\hline Subsoil in fall & 726 & 488 & 1214 & 719 & 782 & 1501 & 11.2 & 8.96 & 20.16 & 11.2 & 8.96 & 20.2 \\
\hline High stock density grazing & 1189 & 560 & 1749 & 1035 & 795 & 1830 & 15.7 & 6.72 & 22.42 & 13.4 & 11.2 & 24.6 \\
\hline Pasture rest & 768 & 493 & 1261 & 806 & 520 & 1326 & 13.4 & 17.9 & 31.3 & 11.2 & 15.7 & 26.9 \\
\hline Mean & 1072 & 566 & & 1025 & 752 & & 14.4 & 12.5 & & 13.4 & 12.5 & \\
\hline Significance (T x D) & \multicolumn{2}{|c|}{$* * *$} & \multicolumn{4}{|c|}{$* * *$} & \multicolumn{2}{|c|}{$* * *$} & \multicolumn{4}{|c|}{$* * *$} \\
\hline $\mathrm{LSD}_{0.05}(\mathrm{~T} \times \mathrm{D})$ & \multicolumn{2}{|c|}{33.2} & \multicolumn{4}{|c|}{78} & \multicolumn{2}{|c|}{2.66} & \multicolumn{4}{|c|}{2.31} \\
\hline $\mathrm{CV}, \%$ & \multicolumn{2}{|c|}{2.19} & \multicolumn{4}{|c|}{4.48} & \multicolumn{2}{|c|}{10.9} & \multicolumn{4}{|c|}{2.95} \\
\hline
\end{tabular}

Z, T x D, treatment (rejuvenation methods) x soil depths interaction.

$* * *$, significant at $\mathrm{P}<0.001$.

$\mathrm{LSD}_{0.05}$, least significant difference at $P<0.05$.

$\mathrm{CV}$, coefficient of variation

The surface soil P was consistently higher for BG, M+S and HSGD than other methods of rejuvenation. In 2016, 
$\mathrm{M}+\mathrm{S}$ in fall had the most surface soil $\mathrm{P}$, while in 2017, BG showed higher surface soil $\mathrm{P}$ value. In 2016, surface soil had more soil P than subsurface soil. In 2017, in most cases, surface soil P was similar or slightly lower than subsurface soil P. Combining the 2 depths $(0-5 \mathrm{~cm}+15-30 \mathrm{~cm})$, BG and $\mathrm{M}+\mathrm{S}$, consistently had higher soil $\mathrm{P}$ than other methods including in both years (2016 \& 2017). The increases in soil P for BG over check were 43 and $40 \mathrm{~kg} \mathrm{ha}^{-1} \mathrm{P}$ in 2016 and 2017 respectively. For $\mathrm{M}+\mathrm{S}$, the increases over check were as high as $110 \mathrm{~kg} \mathrm{ha}^{-1} \mathrm{P}$ in 2016 and $25 \mathrm{~kg} \mathrm{ha}^{-1} \mathrm{P}$ in 2017.

The surface soil K was higher for BG, M+S in fall and HSDG than other methods of rejuvenation in 2016. At the same depth, the surface soil $\mathrm{K}$ was similar for both years for most methods of rejuvenation. In both years (2016 and 2017), the surface soil $\mathrm{K}$ was mostly higher than subsurface soil K. Combining the 2 depths, BG and M+S, consistently had higher soil $\mathrm{K}$ than other methods including in both years (2016 \& 2017). The increases in soil $\mathrm{K}$ for BG over check were 34 and 36\% in 2016 and 2017 respectively. While for M+S, the increases over check were as high as 32\% in 2016 and $21 \%$ in 2017.

Except for M+S, which had 22.4 to $24.6 \mathrm{~kg} \mathrm{ha}^{-1} \mathrm{~S}$ from both soil depths, other methods did not appear to change much in soil $\mathrm{S}$ at both soil depths in both years $(2016 \& 2017)$. Both $\mathrm{M}+\mathrm{S}$ and pasture rest seemed to be consistently higher for soil $\mathrm{S}$ for both depths combined $(0-30 \mathrm{~cm})$ than other methods.

\subsection{Site 2: Grovedale Alberta}

\subsubsection{Soil Physical Properties}

Soil Water Content - The soil water content (Table 9) was similar ( $\mathrm{P}>0.05)$ for all methods in 2016, while BG, SSF and B\&R significantly improved soil water content than other methods in 2017. While BG and SSF greatly improved soil water from 2016 to 2017 by $9.8 \%$ and $4.4 \%$ respectively, other methods had far less improvement in soil water in 2017 than 2016.

Water Infiltration Rate - The water infiltration rate (Table 9) was influenced $(\mathrm{P}<0.05)$ by rejuvenation methods in both years (2016 \& 2017). In 2016, infiltration rate was greatly improved by SSF and B\&R than other methods. In 2017, the top 3 methods and their order with respect to water infiltration rate were: SSF > $(24.0 \mathrm{~mm} / \mathrm{hour})>$ BG $(19.6 \mathrm{~mm} /$ hour $)>$ B\&R (12.4 mm/hour). Infiltration rate generally increased from 2016 to 2017 for all methods (except for B\&R and SSF). The greatest increases in water infiltration rate in 2017 over that of 2016 was recorded for BG. The rate at which water infiltrated into the soil was the same for SSF for both years.

Soil Compaction - The methods of rejuvenation tested here had significant effects $(\mathrm{P}<0.05)$ on soil compaction (Table 9) in both years (2016 \& 2017). Averaged across the various soil depths $(2.5$ to $30 \mathrm{~cm})$ for each year, the mean soil compaction for the rejuvenation methods was lowest for SSF, followed by BG and B\&R in that order for both years. However, pooled across years (2016 \& 2017), soil compaction for methods of rejuvenation at different depths showed that SSF, followed by B\&R had the least compacted soil from 2.5 to $30 \mathrm{~cm}$ soil depths (Figure 2). BG also showed less compacted soil particularly in the surface soil (2.5-15 cm soil depth, Figure 2).

Table 9. Gravimetric soil moisture content, water infiltration rate and soil compaction (average of 0-30 cm interval) in 2016 and 2017 at Site 2: Grovedale Alberta

\begin{tabular}{lllllll}
\hline \multirow{2}{*}{ Rejuvenation Method } & \multicolumn{2}{l}{ Soil moisture $(\%)$} & \multicolumn{2}{l}{ Infiltration $(\mathrm{mm} / \mathrm{hr})$} & \multicolumn{2}{l}{ Compaction $\left(\mathrm{kg} \mathrm{cm}^{-2}\right)$} \\
\cline { 2 - 6 } & 2016 & 2017 & 2016 & 2017 & 2016 & 2017 \\
\hline Check & 13.0 & 10.0 & 1.27 & 7.37 & 29.5 & 31.4 \\
Bale grazing & 11.6 & 21.4 & 6.60 & 19.6 & 18.8 & 15.2 \\
Break \& re-seed & 12.7 & 14.4 & 20.6 & 12.4 & 24.7 & 16.5 \\
Fertilizer application & 11.1 & 10.0 & 1.27 & 5.59 & 27.3 & 30.7 \\
High stock density grazing & 10.1 & 11.9 & 1.78 & 4.83 & 32.6 & 30.4 \\
Subsoil in fall & 12.1 & 16.5 & 23.9 & 24.0 & 10.1 & 14.3 \\
\hline Mean & 11.8 & 14.0 & 9.2 & 12.3 & 23.8 & 23.1 \\
Significance & $\mathrm{NS}^{\mathrm{Z}}$ & $* *$ & $* * *$ & $* * *$ & $* * *$ & $* * *$ \\
LSD & 5.90 & 1.66 & 3.12 & 4.49 & 8.36 & 6.06 \\
$\mathrm{CV}, \%$ & 11.9 & 7.82 & 24.5 & 25.9 & 13.7 & 14.1 \\
\hline
\end{tabular}

${ }^{\mathrm{z}}$, NS, not significant at $P<0.05$.

** and ***, significant at $P<0.01$ and $\mathrm{P}<0.001$, respectively.

$\mathrm{LSD}_{0.05}$, least significant difference at $P<0.05 ; \mathrm{CV}$, coefficient of variation. 


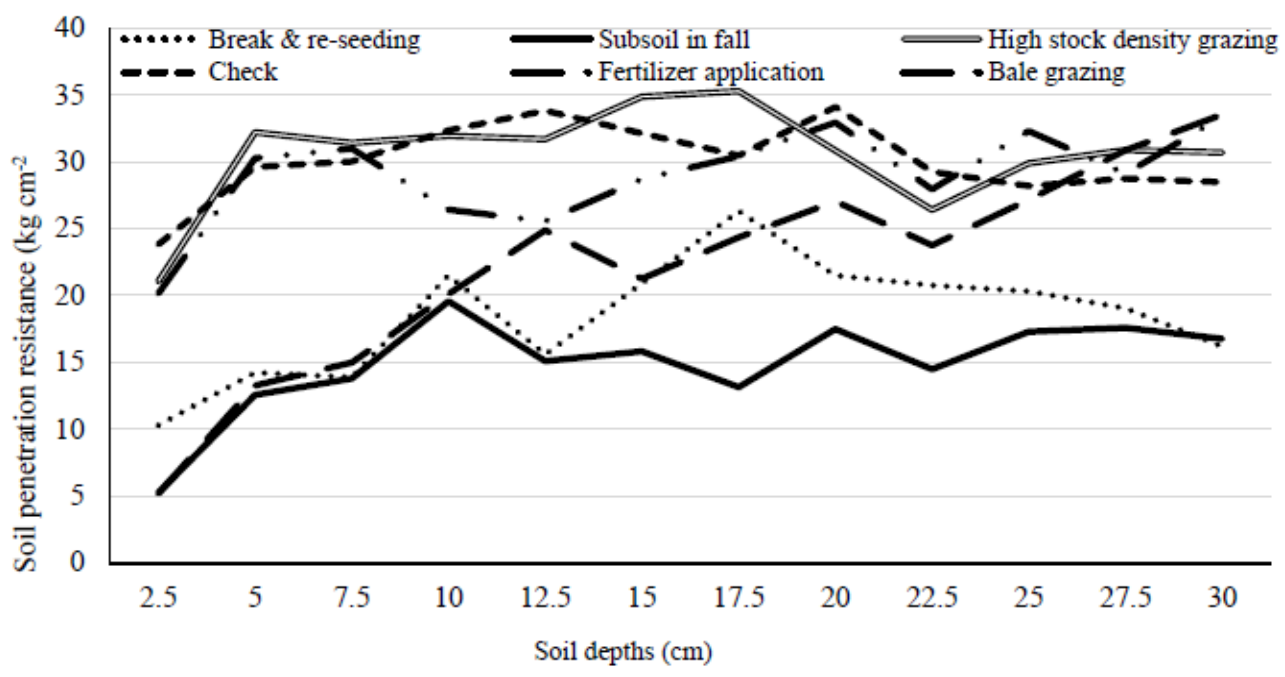

Figure 2. The mean (pooled over 2016 \& 2017) soil compaction from 0 to $30 \mathrm{~cm}$ for different rejuvenation methods at Site 2: Grovedale Alberta. Significance: *** $(\mathrm{P}<0.001) ; \mathrm{LSD}_{0.05}: 6.86$; Cofficient of variation $(\%)$ :

14.2

\subsubsection{Soil Chemical Properties}

Soil $\mathrm{pH}$ - The soil $\mathrm{pH}$ was not significantly affected $(P>0.05)$ by methods of pasture rejuvenation (Table 10$)$.

Soil Organic Matter (SOM) - The SOM consistently affected by rejuvenation methods $\mathrm{x}$ soil depth interaction in both years. In both years, BG appeared to have consistently higher SOM values from surface soil depth than other methods of rejuvenation (Table 10). In 2017, BG favoured SOM by $1.70-3.80 \%$ over other methods including Check. The SOM value was generally higher in the surface soil than subsoil in both years for all rejuvenation methods investigated.

Electrical Conductivity (EC) - In both years, EC was influenced by method x soil depth interaction and BG consistently showed higher soil EC values than other methods in the surface soil $(0-15 \mathrm{~cm})$ (Table 10).

Table 10. Soil pH, soil organic matter (SOM) and electrical conductivity *EC) from 2 depths [0-15 cm (D1) and 15-30 cm (D2)] in 2016 and 2017 at Site 2: Grovedale Alberta

\begin{tabular}{|c|c|c|c|c|c|c|c|c|c|c|c|c|}
\hline \multirow{3}{*}{ Rejuvenation method } & \multicolumn{4}{|c|}{$\mathrm{pH}$} & \multicolumn{4}{|c|}{$\operatorname{SOM}(\%)$} & \multicolumn{4}{|c|}{$\mathrm{EC}(\mathrm{ds} / \mathrm{m})$} \\
\hline & \multicolumn{2}{|c|}{2016} & \multicolumn{2}{|c|}{2017} & \multicolumn{2}{|c|}{2016} & \multicolumn{2}{|c|}{2017} & \multicolumn{2}{|c|}{2016} & \multicolumn{2}{|c|}{2017} \\
\hline & D1 & D2 & D1 & D2 & D1 & D2 & D1 & D2 & D1 & D2 & D1 & D2 \\
\hline Check & 6.70 & 6.40 & 7.50 & 7.40 & 3.93 & 2.00 & 4.95 & 0.40 & 0.34 & 0.23 & 0.22 & 0.07 \\
\hline Bale grazing & 6.90 & 6.70 & 7.10 & 7.10 & 7.20 & 1.40 & 7.00 & 3.50 & 0.52 & 0.22 & 0.37 & 0.20 \\
\hline Break \& re-see & 6.60 & 6.80 & 6.80 & 7.10 & 6.60 & 3.50 & 5.50 & 0.40 & 0.27 & 0.26 & 0.20 & 0.07 \\
\hline Fertilizer application & 6.60 & 6.40 & 6.80 & 7.00 & 4.90 & 2.10 & 4.10 & 2.10 & 0.27 & 0.20 & 0.32 & 0.10 \\
\hline High s & 6.50 & 6.80 & 7.00 & 7.00 & 6.75 & 3.80 & 6.20 & 3.20 & 0.27 & 0.26 & 0.21 & 0.20 \\
\hline Subsoil in fall & 6.90 & 6.30 & 6.80 & 7.10 & 6.10 & 2.90 & 6.00 & 2.80 & 0.29 & 0.29 & 0.32 & 0.10 \\
\hline Mean & 6.9 & 6.9 & 6.9 & 7 & 7.5 & 4.2 & 6.8 & 4.9 & 0.35 & 0.26 & 0.26 & 0.25 \\
\hline Significance $(T \times D)^{\mathrm{z}}$ & \multicolumn{2}{|c|}{$\mathrm{NS}^{\mathrm{y}}$} & \multicolumn{2}{|c|}{ NS } & \multicolumn{2}{|c|}{$* * *$} & \multicolumn{2}{|c|}{$* * *$} & \multicolumn{2}{|c|}{$* * *$} & \multicolumn{2}{|c|}{$* * *$} \\
\hline $\mathrm{LSD}_{0.05}(\mathrm{~T} \times \mathrm{D})$ & \multicolumn{2}{|c|}{0.51} & \multicolumn{2}{|c|}{3.06} & \multicolumn{2}{|c|}{0.56} & \multicolumn{2}{|c|}{1.4} & \multicolumn{2}{|c|}{0.09} & \multicolumn{2}{|c|}{0.07} \\
\hline $\mathrm{CV}, \%$ & \multicolumn{2}{|c|}{1.22} & \multicolumn{2}{|c|}{2.10} & \multicolumn{2}{|c|}{7.00} & \multicolumn{2}{|c|}{9.18} & \multicolumn{2}{|c|}{3.00} & \multicolumn{2}{|c|}{2.19} \\
\hline
\end{tabular}

${ }^{\mathrm{z}}, \mathrm{T}$ x D, treatment (rejuvenation methods) x soil depths interaction.

${ }^{\mathrm{y}}$, NS, not significant at $P<0.05$

***, significant at $\mathrm{P}<0.001$.

$\mathrm{LSD}_{0.05}$, least significant difference at $P<0.05$.

$\mathrm{CV}$, coefficient of variation.

Total C and N, and C:N ratio (Table 11) - In both years (2016 \& 2017), the soil C and N were significantly affected by rejuvenation methods $\mathrm{x}$ soil depth interaction, but not the resulting $\mathrm{C}: \mathrm{N}$ ratios. The significant interaction effects for both soil $\mathrm{C}$ and $\mathrm{N}$ in both years showed that in all cases, soil $\mathrm{C}$ and $\mathrm{N}$ were significantly lower at the sub-surface soil $(15-30 \mathrm{~cm})$ than soil $\mathrm{C}$ and $\mathrm{N}$ at the surface soil $(0-15 \mathrm{~cm})$. In both years and at both soil depths, HSDG consistently had higher Soil C than other methods. Just as the resulting C:N ratios, which did 
not show any significant rejuvenation methods $\mathrm{x}$ soil depth interaction, in both years, pooled over soil depths, the $\mathrm{C}: \mathrm{N}$ ratios were also similar for all rejuvenation methods (data not shown).

Table 11. Soil total $\mathrm{C}$ and $\mathrm{N}$ and their ratios (C:N) from 2 depths [0-15 cm (D1) and 15-30 cm (D2)] in 2016 and 2017 at Site 2: Grovedale Alberta

\begin{tabular}{|c|c|c|c|c|c|c|c|c|c|c|c|c|}
\hline \multirow{3}{*}{ Rejuvenation Method } & \multicolumn{4}{|c|}{$\mathrm{C} \%$} & \multicolumn{4}{|c|}{$\mathrm{N} \%$} & \multicolumn{4}{|c|}{$\mathrm{C}: \mathrm{N}$ ratio } \\
\hline & \multicolumn{2}{|c|}{2016} & \multicolumn{2}{|c|}{2017} & \multicolumn{2}{|c|}{2016} & \multicolumn{2}{|c|}{2017} & \multicolumn{2}{|c|}{2016} & \multicolumn{2}{|c|}{2017} \\
\hline & D1 & D2 & D1 & D2 & D1 & D2 & D1 & D2 & D1 & $\mathrm{D} 2$ & D1 & D2 \\
\hline Check & 3.73 & 1.07 & 3.11 & 1.03 & 0.28 & 0.10 & 0.23 & 0.08 & 13.3 & 10.7 & 13.5 & 12.9 \\
\hline Bale grazing & 4.01 & 0.61 & 3.92 & 0.89 & 0.24 & 0.06 & 0.24 & 0.09 & 16.7 & 10.2 & 16.3 & 9.9 \\
\hline Break \& re-seed & 3.56 & 1.79 & 3.09 & 1.52 & 0.26 & 0.14 & 0.20 & 0.08 & 13.7 & 12.8 & 15.5 & 19.0 \\
\hline Fertilizer & 2.83 & 0.70 & 2.93 & 0.65 & 0.20 & 0.05 & 0.18 & 0.05 & 14.2 & 14.0 & 16.3 & 13.0 \\
\hline Subsoil in fall & 3.89 & 1.16 & 2.95 & 0.89 & 0.28 & 0.09 & 0.21 & 0.07 & 13.9 & 12.9 & 14.0 & 12.7 \\
\hline High stock density grazing & 5.29 & 3.38 & 3.58 & 2.34 & 0.29 & 0.21 & 0.26 & 0.19 & 18.2 & 16.1 & 13.8 & 12.3 \\
\hline Mean & 3.89 & 1.45 & 3.26 & 1.22 & 0.26 & 0.11 & 0.22 & 0.09 & 15 & 12.8 & 14.9 & 13.3 \\
\hline Significance & \multicolumn{2}{|c|}{$* * *$} & \multicolumn{2}{|c|}{$* * *$} & \multicolumn{2}{|c|}{$*$} & \multicolumn{2}{|c|}{$*$} & \multicolumn{2}{|c|}{$\mathrm{NS}^{\mathrm{z}}$} & \multicolumn{2}{|c|}{ NS } \\
\hline $\mathrm{LSD}_{0.05}$ & \multicolumn{2}{|c|}{1.23} & \multicolumn{2}{|c|}{1.08} & \multicolumn{2}{|c|}{0.09} & \multicolumn{2}{|c|}{0.07} & \multicolumn{2}{|c|}{3.23} & \multicolumn{2}{|c|}{2.81} \\
\hline $\mathrm{CV}, \%$ & \multicolumn{2}{|c|}{5.23} & \multicolumn{2}{|c|}{4.98} & \multicolumn{2}{|c|}{1.23} & \multicolumn{2}{|c|}{2.18} & \multicolumn{2}{|c|}{3.33} & \multicolumn{2}{|c|}{2.54} \\
\hline
\end{tabular}

${ }^{\mathrm{Z}}$, NS, not significant at $P<0.05$.

****, significant at $\mathrm{P}<0.05$ and $\mathrm{P}<0.001$ respectively.

$\mathrm{LSD}_{0.05}$, least significant difference at $P<0.05$.

$\mathrm{CV}$, coefficient of variation.

Soil Nutrients (Table 12) - In both years, soil N, P, K and S were significantly affected $(P<0.05)$ by rejuvenation methods $\mathrm{x}$ soil depth interaction.

In both years, BG consistently improved soil $\mathrm{N}$ in the surface soil than other methods. In 2016, other than BG, which showed higher soil $\mathrm{N}$ at $0-15 \mathrm{~cm}$ than $15-30 \mathrm{~cm}$, other methods mostly had similar soil $\mathrm{N}$ at both depths. In 2017, BG also, as well as FA, HSDG and B\&R seemed to have increased the amount of soil N in the surface soil $(0-15 \mathrm{~cm})$ than subsurface soil $(15-30 \mathrm{~cm})$. In 2016 , subsurface soil $\mathrm{N}$ did not change much with respect to methods investigated, but in 2017, BG, FA, HSDG and SSF had substantially increased subsurface $(15-30 \mathrm{~cm})$ soil $\mathrm{N}$ by up $\sim 7-20 \mathrm{~kg} \mathrm{ha}^{-1} \mathrm{~N}$. In 2016 and 2017, BG consistently showed higher soil $\mathrm{N}$ than other methods including. In 2016, BG had $\sim 52 \mathrm{~kg} \mathrm{ha}^{-1}$ soil $\mathrm{N}$ than check in the $0-30 \mathrm{~cm}$ soil depth, while in 2017 , the increase from $\mathrm{BG}$ over check was $83 \mathrm{~kg} \mathrm{ha}^{-1} \mathrm{~N}$.

The soil P did not differ much in 2016 between the different methods, but in 2017, BG showed significant soil P improvement in both surface and subsurface soil depths than other methods examined in this study. BG had $\sim 27$ to $40 \mathrm{~kg} \mathrm{ha}^{-1} \mathrm{P}$ more than other methods in the surface soil. Generally, BG, FA and HSDG showed more soil P in the surface soil in 2017 than 2016. In both years (except for BG in 2017), subsurface soil mostly had similar soil $\mathrm{P}$ values for any particular treatment.

Only BG showed greater improvement in soil K over Check treatment in the surface soil in both years. The surface soil mostly had higher soil $\mathrm{K}$ than subsurface soil in both years.

Soil S - For some reason, Check appeared to have higher surface soil S in 2016 and 2017 than other methods. Generally, the different methods did not show any consistent trend with respect to soil S from 2016 to 2017. 
Table 12. Soil nutrients $(\mathrm{N}, \mathrm{P}, \mathrm{K} \& \mathrm{~S})$ from 2 depths $(0-15 \mathrm{~cm}$ and $15-30 \mathrm{~cm})$ in 2016 and 2017 at Site 2: Grovedale Alberta

\begin{tabular}{|c|c|c|c|c|c|c|c|c|c|c|c|c|}
\hline \multirow{3}{*}{ Rejuvenation Method } & \multicolumn{6}{|c|}{$\mathrm{N}\left(\mathrm{kg} \mathrm{ha}^{-1}\right)$} & \multicolumn{6}{|c|}{$\mathrm{P}\left(\mathrm{kg} \mathrm{ha}^{-1}\right)$} \\
\hline & \multicolumn{3}{|c|}{2016} & \multicolumn{3}{|c|}{2017} & \multicolumn{3}{|c|}{2016} & \multicolumn{3}{|c|}{2017} \\
\hline & D1 & D2 & Total & D1 & D2 & Total & D1 & D2 & Total & D1 & D2 & Total \\
\hline Check & 4.48 & 4.48 & 8.96 & 11.2 & 6.72 & 17.9 & 20.2 & 11.2 & 31.4 & 20.2 & 11.2 & 31.4 \\
\hline Bale grazing & 53.8 & 6.72 & 60.5 & 80.6 & 20.2 & 101 & 22.4 & 13.4 & 35.8 & 58.2 & 29.1 & 87.3 \\
\hline Break \& re-seed & 4.48 & 4.48 & 8.96 & 29.1 & 6.72 & 35.8 & 24.6 & 17.9 & 42.5 & 26.9 & 16.8 & 43.7 \\
\hline Fertilizer application & 8.96 & 6.72 & 15.7 & 31.4 & 26.9 & 58.3 & 15.7 & 13.4 & 29.1 & 31.4 & 15.7 & 47.1 \\
\hline High stock density grazing & 4.48 & 4.48 & 8.96 & 42.6 & 15.7 & 58.3 & 17.9 & 11.2 & 29.1 & 24.6 & 15.7 & 40.3 \\
\hline Subsoil in fall & 4.48 & 6.72 & 11.2 & 15.7 & 13.4 & 29.1 & 17.9 & 11.2 & 29.1 & 17.9 & 11.2 & 29.1 \\
\hline Mean & 13.4 & 5.6 & & 35.1 & 14.9 & & 17.7 & 11.7 & & 26.7 & 14.8 & \\
\hline Significance $(\mathrm{T} \times \mathrm{D})^{\mathrm{Z}}$ & \multicolumn{3}{|c|}{$* * *$} & \multicolumn{3}{|c|}{$* * *$} & \multicolumn{2}{|c|}{$* * *$} & \multicolumn{4}{|c|}{$*$} \\
\hline $\mathrm{LSD}_{0.05}(\mathrm{~T} \times \mathrm{D})$ & \multirow{2}{*}{\multicolumn{2}{|c|}{$\begin{array}{c}3.7 \\
25.4\end{array}$}} & & \multicolumn{2}{|c|}{8.18} & & \multicolumn{2}{|c|}{7.67} & \multicolumn{4}{|c|}{11.8} \\
\hline $\mathrm{CV}, \%$ & & & & \multicolumn{2}{|c|}{17.10} & & \multicolumn{2}{|c|}{18.4} & \multicolumn{4}{|c|}{22.70} \\
\hline
\end{tabular}

\begin{tabular}{|c|c|c|c|c|c|c|c|c|c|c|c|c|}
\hline \multirow{3}{*}{ Rejuvenation Method } & \multicolumn{6}{|c|}{$\mathrm{K}\left(\mathrm{kg} \mathrm{ha}^{-1}\right)$} & \multicolumn{6}{|c|}{$\mathrm{S}\left(\mathrm{kg} \mathrm{ha}^{-1}\right)$} \\
\hline & \multicolumn{3}{|c|}{2016} & \multicolumn{3}{|c|}{2017} & \multicolumn{3}{|c|}{2016} & \multicolumn{3}{|c|}{2017} \\
\hline & D1 & D2 & Total & D1 & D2 & Total & D1 & D2 & Total & D1 & D2 & Total \\
\hline Check & 448 & 352 & 800 & 562 & 251 & 813 & 20.2 & 13.4 & 33.6 & 15.7 & 4.48 & 20.18 \\
\hline Bale grazing & 1044 & 249 & 1293 & 795 & 379 & 1174 & 11.2 & 6.72 & 17.9 & 15.7 & 8.96 & 24.66 \\
\hline Break \& re-seed & 497 & 318 & 815 & 737 & 128 & 865 & 11.2 & 11.2 & 22.4 & 11.2 & 2.24 & 13.44 \\
\hline Fertilizer application & 428 & 370 & 798 & 741 & 220 & 961 & 6.72 & 4.48 & 11.2 & 8.96 & 6.72 & 15.68 \\
\hline High stock density grazing & 473 & 403 & 876 & 538 & 374 & 912 & 8.96 & 6.72 & 15.7 & 6.72 & 6.72 & 13.44 \\
\hline Subsoil in fall & 520 & 437 & 957 & 616 & 213 & 829 & 13.4 & 11.2 & 24.6 & 13.4 & 8.96 & 22.36 \\
\hline Mean & 568 & 355 & & 665 & 261 & & 11.9 & 8.96 & & 11.9 & 6.35 & \\
\hline Significance $(T \times D)^{Z}$ & \multicolumn{2}{|c|}{$* * *$} & \multicolumn{4}{|c|}{$* * *$} & \multicolumn{2}{|c|}{$* * *$} & \multicolumn{4}{|c|}{$* * *$} \\
\hline $\mathrm{LSD}_{0.05}(\mathrm{~T} \times \mathrm{D})$ & \multicolumn{2}{|c|}{146} & \multicolumn{4}{|c|}{30} & \multicolumn{2}{|c|}{6.22} & \multicolumn{4}{|c|}{3.43} \\
\hline $\mathrm{CV}, \%$ & \multicolumn{2}{|c|}{17.3} & \multicolumn{4}{|c|}{13.4} & \multicolumn{2}{|c|}{23.9} & \multicolumn{4}{|c|}{19.7} \\
\hline
\end{tabular}

${ }^{\mathrm{Z}}$, T x D, treatment (rejuvenation methods) x soil depths interaction.

$*$,***, significant at $\mathrm{P}<0.05$ and $\mathrm{P}<0.001$ respectively.

$\mathrm{LSD}_{0.05}$, least significant difference at $P<0.05$.

$\mathrm{CV}$, coefficient of variation

\section{Discussion}

Under pasture production systems, changes in soil quality can be assessed by measuring appropriate indicators and comparing them with desired values (critical limits or threshold level) at regular intervals. Such a monitoring systems will provide information on the effectiveness of the production systems.

\subsection{Soil Organic Matter (SOM)}

In the present study, the initial SOM in the surface soil $(0-15 \mathrm{~cm})$ was $5.2 \%$ at site 1 and $6.9 \%$ at site 2 before the rejuvenation methods were implemented. After the methods were implemented, most methods seemed to have some positive effects on SOM over the duration of this study. Overall, bale grazing system as a method of rejuvenation improved SOM by up to $3.80 \%$ over other methods including check during the study period. A high stock density grazing, and to some extent, manure + subsoil in fall (though only done at one site) have both also showed great potential for improving SOM. The slight increases in SOM over a short duration as recorded in this study would be significant for sustainable pasture production and livestock carrying capacity. This is because SOM is an important source of inorganic nutrients for plant production in natural and managed ecosystems. The improvement in SOM by bale grazing in this study was not unexpected as various previous studies in the same environment (Omokanye, 2013, 2014) and elsewhere (Henke, 2017) have all reported similar observations. As observed here with respect to the differences in SOM between soil layers, previous studies by Omokanye (2013, 2014) also obtained higher SOM in the surface soil $(0-15 \mathrm{~cm})$ than subsurface soil $(15-30 \mathrm{~cm})$.The significant increases in surface soil SOM particularly from bale grazing and manure + subsoiling over check and some of the other methods investigated in this study could be attributed to the benefits of cow feces and urine and stockpile manure, which would provide greater diversity and activity of organisms (such as increases in earthworm and dung beetle population) and better soil structure (Brown, 2015).

\subsection{Soil Electrical Conductivity}

Soluble salts are present in soils; however, when the concentration of salts is high, the soil is considered saline and crop growth can be reduced. Following the salinity ratings for Alberta soils in relation to EC measurements 
(Kryzanowski et al., 1988), it is evident that from the results of EC obtained in this study at both sites from both surface and subsurface soil layers, the soils at both sites were non-saline as they were generally $<0.60 \mathrm{dS} / \mathrm{m} \mathrm{EC}$.

\subsection{Soil $p H$}

Soil $\mathrm{pH}$ (or reaction) indicates acidity or alkalinity of the soil. Soil $\mathrm{pH}$ is also a useful tool in making management decisions concerning the type of plants suitable for location, the possible need to modify soil $\mathrm{pH}$ (either up or down), and a rough indicator of the plant availability of nutrients in the soil. Under low $\mathrm{pH}$ conditions, some nutrients bind tightly to soil particles and as a result are unavailable to plants (AAF, 2008). Low $\mathrm{pH}$ conditions also impact the growth and survival of soil microorganisms, some of which are instrumental in releasing nutrients bound in organic matter for crop use, while crops produced in soils more acidic than their tolerance level will result in reduced yields. In the present study, soil $\mathrm{pH}$ values were within optimal levels for crop growth and soil microbial activity (Smith \& Doran, 1996), an indication that many forages will do well in both soils.

\subsection{Soil Compaction Penetration Resistance}

In northern Alberta, soil compaction is one of the main problems for forage production. It is essential to implement strategies to prevent soil compaction. Remediation of compaction through subsoiling is one approach. In the present study, the high soil compaction readings obtained from check and most rejuvenation methods other than bale grazing, break \& reseed and the 2 subsoiling treatments, further confirms that, soils under pastures can be severely compacted - an issue mostly attributable to the heavy textured type of soils (Omokanye, 2015) and cattle trampling in pastures. Soil compaction can impair water infiltration into soil, root penetration and nutrient uptake. Furthermore, soil compaction could reduce soil respiration by reducing pore space and limiting $\mathrm{O}_{2}$ diffusion (Collin \& van der Driessche, 2000; Shestak \& Busse, 2005). Penetration resistance has been related to crop root growth in wet soils close to the drained upper limit. In general, crop root growth restriction starts when penetration resistance exceeds $15 \mathrm{~kg} \mathrm{~cm}^{-2}$ and severe restriction at $25 \mathrm{~kg} \mathrm{~cm}^{-2}$ or more in soils at field capacity (Davis \& Isbister, 2017). Soil compaction readings of $>21 \mathrm{~kg} \mathrm{~cm}^{-2}$ would indicate potential soil compaction in the field (Murdock et al., 1995).

In the present study, subsoiling was done only to $30 \mathrm{~cm}$ deep and was considered shallow compacted layer. When properly done, subsoiling loosens the soil allowing roots to penetrate deeper into the profile, increasing water infiltration, and improving conditions conducive to biological activity (Weill, 2015). The advantage of Agrowplow subsoiler used in this study is that the degree of soil surface disturbance is usually very minimal.

The present study shows that, in addition to break and reseed as a means of pasture renewal and for temporarily reducing compaction, other reliable options that producers can use in reducing compaction would be bale grazing and subsoiling. It is important to note that bale grazing however may not always have significant reduction in compaction beyond $15 \mathrm{~cm}$ soil depth.

\subsection{Soil Water Infiltration}

Comparing with the permeability classification system provided by UNCE (1999) to describe soil water infiltration performance, other than check (except at site 2 in 2017) which was very slow in allowing water into soil, most methods investigated belonged to moderately slow permeability class. The greater water infiltration rates from the two subsoiling treatment methods over check in particular showed the value of deep tillage method such as subsoiling in breaking up soil compaction and thereby allowing significant water movement though the soil.

\subsection{Total soil C}

In the present study, the soil $\mathrm{C}$ tended to be higher with break and reseed, manure + subsoiling and subsoiling in the fall than other rejuvenation methods at site 1 in the surface soil in 2016 (but not in 2017) and this did not appear to be so at site 2 at the same soil depth. Also, there appeared to be a generally lower soil $\mathrm{C}$ in the surface soil in 2017 than 2016 at both sites for all methods of rejuvenation. What could be responsible for these observations is not very clear. Therefore, further long-term studies are needed to enable a true picture of soil C under different pasture improvement methods. This is very important in order to understand the dynamics of soil C storage under pastures, as Brady \& Weil (2008) earlier pointed out, that the potential for C sequestration is greatest on degraded lands, where current levels of carbon may represent a fraction of what naturally occurred. It is also important to note that, in addition to various inorganic forms, $\mathrm{C}$ can be stored in the soil as SOM (Brady \& Weil, 2008). A large number of factors affect the build-up of soil C, including climate, rainfall, vegetation, topography, soil properties and drainage. The observation that $\mathrm{C}: \mathrm{N}$ ratio was generally lower in subsoil than in topsoil in this study is in conformity with earlier report by Cathcart (2003). 


\subsection{Soil N, $P, K$ and $S$}

The findings from this study as expected showed that check, break \& reseed and subsoiling in fall did not appear to have any influence on soil $\mathrm{NO}_{3}-\mathrm{N}$. However, later in the present study, bale grazing significantly improved soil $\mathrm{N}$ (up to $96 \mathrm{~kg} \mathrm{ha}^{-1}$ from 0-30 $\mathrm{cm}$ ) than other rejuvenation methods investigated. With bale grazing, through the residual feed/feed litter and manure accumulation, $\mathrm{N}$ is captured on the bale grazing site and gradually becomes available through litter decomposition and soil nutrient mineralization for subsequent pasture production (Jungnitsch et al., 2011; Omokanye, 2013, 2014; Picard, 2010). In 2016, at site 1, high stock density grazing had the most soil $\mathrm{N}$, but by 2017 , the soil $\mathrm{N}$ had reduced sharply by $63 \mathrm{~kg} \mathrm{ha}^{-1}$, indicating that soil $\mathrm{N}$ was probably lost from the soil of high stock density grazing method through leaching and runoff, a problem which had earlier been identified with bale grazing system in the same environment (Omokanye, 2014). Environmental concerns also dictate the need for careful manure management planning, as the $\mathrm{N}$ in manure may be converted through the action of soil bacteria to the nitrate form which, if unused by plants, can move through the soil and into the groundwater (Madison et al., 1995). Movement of nitrate to groundwater is more likely to be a problem in areas with sandy soils and a water table near the land surface.

Crop yield is determined by the supply of individual nutrients relative to their required levels for optimal yield. Nitrogen is a key component of soil organic matter and is required by plants in large quantities. It is often the first limiting nutrient in prairie cropping systems (including northern Alberta) in Canada (AAF, 2008). Looking at the generalized deficient, marginal, and adequate ranges of various crop nutrients for Alberta soils as provided by Kryzanowski et al. (1988), it is evident that in the present study, bale grazing and high stock density grazing (particular at site 1), would potentially be able to provide sufficient soil $\mathrm{N}$ for yearly forage production. Our results showed that most rejuvenation methods were generally deficient in soil $\mathrm{N}$ for optimum forage production.

The inability of high stock density grazing at site 2 was because of the lower number of animals used at that site than site 1, indicating that the lower number of animals in that treatment was not able to provide the same effect at that particular point in time. Though, manure + subsoiling, occasional pasture rest and fertilizer application methods of rejuvenation did not seem to improve soil $\mathrm{NO}_{3}-\mathrm{N}$ in 2016, but over time (in 2017), they all showed potential to improve soil $\mathrm{NO}_{3}-\mathrm{N}$ in their respective systems. What was responsible for the inability of fertilized pasture treatment to show any initial improvement in soil $\mathrm{N}$ particularly in 2016 is difficult to explain? Being an organic nutrients source, the manure in manure + subsoiling would slowly release its $\mathrm{N}$, thereby improving soil $\mathrm{N}$ over time as observed here with manure + subsoiling treatment. Organic $\mathrm{N}$ compounds are an important source of $\mathrm{N}$ for crops. These compounds, which are part of soil organic matter, must undergo decomposition before the $\mathrm{N}$ they contain is plant available.

Phosphorus is regarded as the second most limiting nutrient in western Canadian soils (AAF, 2008). In the present study, soil P levels were generally higher at site 1 than site 2 , and this was associated to the initial (base data taken in 2015, see Table 1) generally high soil P levels at site 1 (18-19 ppm P) compared to site 2 (7-9 ppm $\mathrm{P})$. At site 1, most methods had adequate soil P levels for plant growth. But overall, at site, bale grazing, manure + subsoil and high stock density grazing consistently had higher soil P levels. One of the environmental concerns of manure application is that high $\mathrm{P}$ contained in manure can affect lake and stream water quality by stimulating weed and algae growth (Madison et al., 1995). At site 2, where the initial soil P was low, of the methods tested, only bale grazing was able to meet the required soil P level needed for proper plant growth under a dry land situation in Alberta (Kryzanowski et al., 1988).

In this study, at both sites and for all rejuvenation methods, soil $\mathrm{K}$ levels generally far exceeded the commonly recommended K for plant growth (Kryzanowski et al., 1988). The lack of any soil K deficiencies by any of the rejuvenation methods at both sites probably suggests that $\mathrm{K}$ may not be a problem in the soil under a pasture/grazing situation. Again, site 1 generally had higher soil $\mathrm{K}$ than site 2, a reflection of the initial higher soil $\mathrm{K}$ at site 1 (particularly from $0-15 \mathrm{~cm}$ soil layer) than site 2 . Also, as indicated, only a small percentage of the total arable land on the prairies in Canada is K deficient (AAF, 2008). Though, the highest proportion of these $\mathrm{K}$ deficient soils is in Alberta, particularly on the coarse textured (sandier) soils. None of the 2 sites used in the present study had coarse textured (sandier) soils.

Though only 3 of the overall 8 methods tested at one point seemed to be within the required soil S levels for proper plant growth, the soil S levels at both sites were generally lower than the recommended soil S levels for plant growth in Alberta under dry land situation (Kryzanowski et al., 1988). Because of the inability of most rejuvenation methods to improve soil $\mathrm{S}$ in this study, additional sources of $\mathrm{S}$ based on soil tests recommendations would be needed for improved pasture production and livestock carrying capacity.

Overall, in terms of soil nutrients (particularly N, P, K and S) at both sites, it is evident from this study that bale 
grazing, manure + subsoil in fall, high stock density grazing and dry fertilizer application have all shown great potential for improving soil N, P, K and S. This study also showed that at both sites in both years (2016 and 2017), the surface soil $(0-15 \mathrm{~cm}) \mathrm{N}, \mathrm{P}$ and $\mathrm{K}$ was mostly higher than subsurface soil $(15-30 \mathrm{~cm}) \mathrm{N}, \mathrm{P}$ and $\mathrm{K}$. The consistently higher soil nutrients (for N, P and K) obtained in this study at both sites mostly for bale grazing, high stock density grazing, manure + subsoil in fall, and dry fertilizer application indicate that inorganic or organic forms of fertilizer would have potential for directly influencing soil nutrients of old pastures.

The findings with using bale grazing, in particular, as a reliable rejuvenation strategy in this study further re-affirms the benefits of bale grazing in adding nutrients to the soil, as earlier reported in various studies across western Canada (Jungnitsch et al., 2011; Picard, 2010) including northern Alberta (Omokanye, 2013). The soil nutrients remain elevated in the surface soil profile but seem to be stabilizing or dropping with increasing years of forage growth and harvest (Picard (2010). As observed in the present study, compared with check, when tillage was used to break up old forage stands, nutrients that were tied up in the organic matter were somehow released over time, particularly with $\mathrm{N}, \mathrm{P}$ and $\mathrm{K}$ at both sites. Though, the release of nutrients could simply be a short-term benefit.

Observations in the present study showed that the grass on the bale grazed areas for bale grazing method was thicker, taller and much darker green with bigger leaves, thereby confirming earlier observations with bale grazing system (Omokanye, 2013). The present study also showed that alfalfa and meadow bromegrass did not do well in bale grazed areas, but smooth bromegrass did grow very well in bale grazed areas. However, quack grass, which most producers see an undesirable native grass in pastures would normally do very well in bale grazed areas. Whether other grass and legume species and varieties would do well or not in bale grazed areas after grazing would needs to be investigated. Further research is still needed to better understand the interactions (of methods investigated in the present study) on the broad spectrum of soil quality indicators (physical, chemical and biological soil properties).

The 3 methods (bale grazing, manure + subsoiling and high stock density grazing) which had some forms of manure showed far greater improvements in soil $\mathrm{N}$ over check and in most cases over other methods as well. This shows the benefits of manure application in improving soil. Soil fertility and balanced soil mineral nutrition are important for both forage and livestock to reach their growth and production potential. Increasing stock density has been shown to increase soil life, soil quality and forage quality at a much faster rate, while still being the most economically rewarding method of grazing (Teague, 2016). Though, the present study did not examine if any of the measured soil quality indicator parameters would have some form of Pearson's correlation coefficient (r) or not, but looking at the findings in this study, we could probable infer that, in order to increase SOM, significant amounts of nutrients such as P, N and S must also be available (Brady \& Weil 2008).

\section{Conclusion}

Maintenance of optimum soil physical conditions is an important component of soil fertility management. In the present study, bale grazing, subsoil in fall, manure + subsoil in fall, and break \& re-seed all consistently played significant roles in improving soil water content and infiltration rate as well as reducing compaction. Subsoil in fall, manure + subsoil in fall and break \& re-seed consistently reduced compaction up to $30 \mathrm{~cm}$ soil depth. Bale grazing also reduced the soil compaction. In addition to the role played by bale grazing in improving soil function, it is important to note that the combination of manure + subsoil in fall may be a good strategy that can be used to enhance soil health through improved SOM, increased infiltration rate and reduced compaction. Though, high stock density grazing may not be able to reduce soil compaction or drastically improve infiltration, but other resulting benefits from high stock density grazing such as improved soil nutrients levels as well as SOM would make it a good choice for rejuvenating old pastures. This study concluded that overall, soil quality indicators measured here, and taking into consideration other potential benefits, the practicable top 4 (bale grazing, subsoil in fall, manure + subsoil in fall, high stock density grazing) methods of rejuvenation that would be recommended to livestock producers there is no doubt that soil health, pasture productivity and farm profitability would increase when the selected methods are properly implemented on old pastures that are still dominated by desirable forage varieties.

\section{Acknowledgements}

This project was supported by funding from the Alberta Crop Industry Development Fund (ACIDF) and is greatly acknowledged. We are thankful to Soames Smith and Bill Smith for providing the project sites, for their interests in the project and for assisting with treatments implementations. We are grateful to Crop Production Services (CPS) and Golden Acre Seeds for fertilizer and forage seed donations. This project was also supported by funding from Agricultural Opportunity Fund (AOF), and municipal districts of Greenview and Spirit River in 
northern Alberta. We thank Graeme Finn of Union Forage for providing the Agrowplow subsoiler and to Lawrence Andruchiw for allowing the use of his manure spreader. Thank you to Dr. Khalil Ahmed for his initial of the manuscript.

\section{References}

AAF (Alberta Agriculture \& Food). (2008). Nutrient Management Planning Guide, Alberta Agriculture and Food. http://www1.agric.gov.ab.ca/\$department/deptdocs.nsf/all/epw11920

Andrews, S. S., Karlen, D. L., \& Cambardella, C. A. (2004). The Soil Management Assessment Framework: A Quantitative Soil Quality Evaluation Method. Soil Sci. Soc. Am. J., 68, 1945-1962. https://doi.org/10.2136/sssaj2004.1945

Brady, N. C., \& Weil, R. R. (2008). The Nature and Properties of Soils, Pearson Prentice Hall.

Brown, C. (2015). What Is The Impact Of Manure On Soil Organic Matter? Ontario Ministry of Agriculture, Food and Rural Affairs. www.omafra.gov.on.ca/english/crops/field/news/croptalk/2015/ct-0615a1.htm

Cathcart, J. (2003). Soil Organic Matter, Alberta Agriculture \& Food. http://www1.agric.gov.ab.ca/\$department/deptdocs.nsf/all/aesa1861

Conlin, T. S. S., \& van den Driessche, R. (2000). Response of soil $\mathrm{CO}_{2}$ and O-2 concentrations to forest soil compaction at the Long-term Soil Productivity sites in central British Columbia. Can. J. Soil Sci., 80, 625-632. https://doi.org/10.4141/S99-085

Davies, S., \& Isbister, B. (2017). Identifying soil compaction. Department of Primary Industries and Regional Development, Gov. of Western Australia. https://www.agric.wa.gov.au/soil-compaction/identifying-soil-compaction

Gardner, W. H. (1986). Water Content. In: A. Klute, editor, Methods of Soil Analysis: Part 1 - Physical and Mineralogical Methods, SSSA Book Ser. 5.1. SSSA, ASA, Madison, WI. p. 493-544. https://doi.org/10.2136/sssabookser5.1.2ed.c21

GenStat. (2009). GenStat for Windows (12 ${ }^{\text {th }}$ Edition). Introduction. VSN International, Hemel Hempstead.

Henke, J. (2017). Bale grazing. Successful farming. November 13, 2017. https://www.agriculture.com/podcast/successful-farming-radio-podcast/bale-grazing

Horn, R., \& Fleige, H. (2009). Risk assessment of subsoil compaction for arable soils in Northwest Germany at farm scale. Soil and Tillage Research, 102, 201-208. https://doi.org/10.1016/j.still.2008.07.015

Jungnitsch, P., Schoenau, J. J., Lardner, H. A., \& Jefferson, P. G. (2011). Winter feeding beef cattle on the western Canadian prairies: Impacts on soil nitrogen and phosphorous cycling and forage growth. Agric. Ecosyst. Environ, 141,143-152. https://doi.org/10.1016/j.agee.2011.02.024

Karlen, D. L., Ditzler, C.A., \& Andrews, S.S. (2003). Soil quality: Why and how? Geoderma, 114, 145-156. https://doi.org/10.1016/S0016-7061(03)00039-9

Karlen, D. L., Mausbach, M. J, Doran, J. W., Cline, R. G, Harris, R. F., \& Schuman, G. E. (1997). Soil quality: A concept, definition, and framework for evaluation. Soil Sci Soc Am J., 61, 4-10. https://doi.org/10.2136/sssaj1997.03615995006100010001x

Kryzanowski, L. (editor), Laverty, D., Ashworth, J., Nyborg, M., Harapiak, J., \& Kucey, R. (1988). Soil test recommendations for Alberta: Technical Manual. Alberta Agriculture, Food \& Rural Development.

Lickacz, J. (1993). Management of solonetzic soils. Agdex 518-8. Revised, Edmonton, Alberta, Canada. http://www1.agric.gov.ab.ca/\$department/deptdocs.nsf/all/agdex166/\$file/518-8.pdf?OpenElement

Lowery, B., Hickey, W. J., Arshad, M. A., \& Lal, R. (1996). Soil water parameters and soil quality. In: Doran J.W., Jones, A.J., editors. Methods for assessing soil quality. Madison, WI. p 143-55.

Linn, D. M., \& Doran, J. W. (1984). Effect of water-filled pore-space on carbon-dioxide and nitrous-oxide production in tilled and nontilled soils. Soil Sci. Soc. Am. J., 48, 1267-1272. https://doi.org/10.2136/sssaj1984.03615995004800060013x

Madison, F., Kelling, K., Massie, L., \& Good, L. W. (1995). Guidelines for applying manure to cropland and pasture in Wisconsin. Univ. of Wisconsin Ext. Publ. A3392. Univ. of Wisconsin, Madison, WI. http://corn.agronomy.wisc.edu/Management/pdfs/A3392.pdf

McKeague, J. A. (1978). Manual on Soil Sampling and Methods of Analysis. 2nd Edition, Canadian Society of 
Soil Science, Ottawa, 212 p.

Murdock, L., Gray, T., Higgins, F., \& Wells, K. (1995). Soil compaction in Kentucky. AGR-161. Lexington, KY: University of Kentucky, Cooperative Extension Service.

Nelson, G., \& Hall, L. (2000). Controlling Quack Grass in Direct Seeding Systems. Alberta, Food and Rural Development. Agdex 519-27. March 2000. http://www1.agric.gov.ab.ca/\$department/deptdocs.nsf/all/agdex3474

Nelson, D. W., \& Sommers, L. E. (1996). Total carbon, organic carbon, and organic matter. p. 961-1010. In: Sparks, D.L. (ed.) Methods of soil analysis. Part 3. Chemical methods. SSSA Book Series No. 5. SSSA and ASA, Madison, WI.

Nicholas P, (Ed.). (2004). Soil, irrigation and nutrition, Grape Production Series 2, SARDI, Adelaide.

NRC (National Research Council). (1996). Nutrient Requirements of Beef Cattle (7th rev. ed.). Natl. Acad. Press, Washington, D.C.

NRC (National Research Council). (2000). Nutrient Requirements of Beef Cattle (7th rev. ed.). Update 2000. Washington, DC: The National Academies Press.

Omokanye, A. T., Yoder, C., Sreekumar, L., Vihvelin, L., \& Benoit, M. (2018). Forage production and economic performance of pasture rejuvenation methods in northern Alberta, Canada. Sustainable Agriculture Research, 7(2), 94-110. https://doi.org/10.5539/sar.v7n2p94

Omokanye, A. T. (2015). Soil health and forage production potential of 6 beef cattle production systems in the Peace. Presentation at Peace Country Beef \& Forage Association Annual General Meeting, DMI, Fairview, Alberta. Canada. February 20, 2015.

Omokanye, A. (2014). Whole farm nutrient budgeting: Soil nutrient changes and forage production (2012-2014). Peace Country Beef \& Forage Association 2014 Annual Report. Pp. 68-81.

Omokanye, A. T. (2013). Soil nutrient trends and forage production following years of bale grazing in parts of the Peace Region of Alberta, Canada. American-Eurasian J. Agric. \& Environ. Sci., 13(6), 877-884. https://doi/10.5829/idosi.aejaes.2013.13.06.11011

Picard, R. (2010). Nutrient cycling in winter grazing cattle on pasture; three years following bale grazing. Manitoba Agronomists Conference Proceedings 2010. [Online].Available at http://umanitoba.ca/afs/ agronomists_conf/2010/poster_pdf/Rejean_Picard_bale_grazing.pdf.

Reynolds, W.D., Drury, C. F., Tan, C. S., Fox, C. A., \& Yang, X. M. (2009). Use of indicators and pore volume-function characteristics to quantify soil physical quality. Geoderma. 152, 252-263. https://doi.org/10.1016/j.geoderma.2009.06.009

Shestak, C. J., \& Busse, M. D. (2005). Compaction alters physical but not biological indices of soil health. Soil Sci. Soc. Am. J.69:236-246. https://doi.org/10.2136/sssaj2005.0236

Smith, J. L., \& Doran, J. W. (1996). Measurement and use of pH and electrical conductivity for soil quality analysis. In: Doran, J.W., Jones, A.J. (Eds.), Methods for Assessing Soil Quality. Soil Sci. Soc. Am. Spec. Publ. 49. SSSA, Madison, WI, pp. 169-185.

Soil Classification Working Group. (1998). The Canadian system for soil classification. Agric. and Agri-Food Canada, Publ.1646. Revised ( $3^{\text {rd }}$ ed.), 187pp.

Statistics Canada. (2012). 2011 Census of Agriculture. Agriculture Statistics. Statistics Canada, Ottawa, released May 10, 2012.

Teague, R. (2016). Managing Upland Grazing to Restore Soil Health and Farm Livelihoods. Wimberley, Texas, 30 ${ }^{\text {th }}$ September, 2016. https://www.ncat.org/wp-content/uploads/2016/11/1Teague2016.pdf

UNCE (University of Nebraska Cooperative Extension). (1999). Soils - Part 2: Physical Properties of Soil and Soil Water - soil water. Soils Home Study Course.

http://passel.unl.edu/pages/index2col.php?alllessons=1\&tag=Soils+Home+Study+Course

Weill, A. (2015). A Guide to Successful Subsoiling. CETAB+, Victoriaville, 43 p. www.cetab.org/publications

Zornoza, R., Acosta, J. A., Bastida, F., Domínguez, S. G., Toledo, D. M., \& Faz, A. (2015). Identification of sensitive indicators to assess the interrelationship between soil quality, management practices and human health. Soil, 1, 173-185. https://doi.org/10.5194/soil-1-173-2015 


\section{Copyrights}

Copyright for this article is retained by the author(s), with first publication rights granted to the journal.

This is an open-access article distributed under the terms and conditions of the Creative Commons Attribution license (http://creativecommons.org/licenses/by/3.0/). 